\title{
INDUÇÃO DE RECEPTOR B1 DE CININAS EM VASOS SANGUINEOS DE RATOS HIPERTENSOS POR INFUSÃO DE ANGIOTENSINA II: ESTUDO MOLECULAR E FUNCIONAL
}

Dissertação apresentada ao Programa de Pós-Graduação em Farmacologia do Instituto de Ciências Biomédicas, da Universidade de São Paulo, para obtenção do Título de Mestre em Ciências. 


\section{INDUÇÃO DE RECEPTOR B1 DE CININAS EM VASOS SANGUINEOS DE RATOS HIPERTENSOS POR INFUSÃO DE ANGIOTENSINA II: ESTUDO MOLECULAR E FUNCIONAL}

Dissertação apresentada ao

Programa de Pós-Graduação em Farmacologia do Instituto de Ciências Biomédicas, da Universidade de São Paulo, para obtenção do Título de Mestre em Ciências.

Área de Concentração: Farmacologia

Orientadora: Prof. Dra. Maria Helena Catelli de Carvalho 
DADOS DE CATALOGAÇÃO NA PUBLICAÇÃO (CIP)

Serviço de Biblioteca e Informação Biomédica do

Instituto de Ciências Biomédicas da Universidade de São Paulo

(C) reprodução total

Giaquinto, Luciana.

Indução de receptor B1 de cininas em vasos sanguineos de ratos hipertensos por infusão de angiotensina II:Estudo molecular e funcional / Luciana Giaquinto. -- São Paulo, 2010.

Orientador: Maria Helena Catelli de Carvalho.

Dissertação (Mestrado) - Universidade de São Paulo. Instituto de Ciências Biomédicas. Departamento de Farmacologia. Área de concentração: Farmacologia. Linha de pesquisa: Reatividade de macro e microvasos em patologias experimentais.Papel do endotélio

Versão do título para o inglês: Induction of kinin B1 receptor in blood vessels of angiotensin II-hypertensive rats:Molecular and functional studies.

Descritores: 1. Hipertensão 2. Angiotensina II $\quad 3$. Receptor B1 4. Cininas 5.Sistema renina angiotensina Estudo molecular e funcional 6. Sistema calicreína cinina I. Carvalho, Maria Helena Catelli de II. Universidade de São Paulo. Instituto de Ciências Biomédicas.Programa de Pós-Graduação em Farmacologia III. Titulo. 
Candidato(a):

Título da Dissertação:

Orientador(a):
Luciana Giaquinto.

Indução de receptor B1 de cininas em vasos sanguineos de ratos hipertensos por infusão de angiotensina II: Estudo molecular e funcional.

A Comissão Julgadora dos trabalhos de Defesa da Dissertação de Mestrado, em sessão pública realizada a ./...................................,
( ) Aprovado(a)
( ) Reprovado(a)

Examinador(a): Assinatura:

Nome:

Instituição:

Examinador(a): Assinatura:

Nome:

Instituição:

Presidente: Assinatura:

Nome:

Instituição: 


\section{Certificado}

Certificamos que o protocolo registrado sob $\mathrm{n}^{\circ} \mathbf{1 4 5}$ nas fls. $\mathbf{9 5}$ do livro 02 para uso de animais em experimentação, sob a responsạbilidade do $\operatorname{Prof(a)} \operatorname{Dr}(a)$ Maria Helena Catelli de Carvalho, Coordenador(a) da Linha de pesquisa Reatividade de macro e microvasos em patologias experimentais. Papel do endotélio do qual participam o(s) alunos Graziela Scalianti Ceravolo, Rosana Marangoni,Fernando Paranaiba Filgueira, Gisele Facholi Bomfim, Luciana dos Reis Rigueiral Giaquinto, Thiago Januário da Costa, Priscila Xavier de Araujo, Cynthia Echem de Souza Pereira, Murilo Lombardo Lopes Pereira, está de acordo com os Princípios Éticos de Experimentação Animal adotado pela Sociedade Brasileira de Ciência de Animais de Laboratório (SBCAL) e foi aprovado pela COMISSÃO DE ÉTICA NO USO DE ANIMAIS (CEUA) em 06.12.2010, com validade de 3 anos.

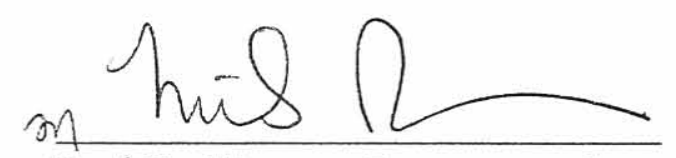

Prof.Dr.WOTHAN TAVARES DE LIMA Coordenador CEUA - ICB/USP
São Paulo, 08 de dezembro de 2010.

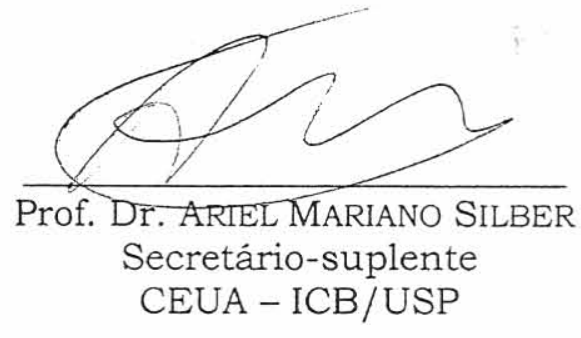




\section{DEDICATÓRIA}

Dedico este trabalho, que significa uma fase importantíssima de minha vida à:

Minha família,

A minha mãe que mesmo de longe me incentivou e apoiou.

Ao meu pai: " Pai onde você estiver espero que esteja orgulhoso, pois se tenho determinação e coragem hoje, foi por me espelhar em você "

Ao meu Marido Francisco que, sem sombra de dúvidas, se não fosse pela sua compreensão e apoio no meu crescimento não teria chegado até aqui.

Aos meus filhos Frederico e Guilhermo, amores da minha vida, que também souberam ter paciência nas horas em que mais precisei, sem contar no estímulo que foram para que eu terminasse essa etapa.

À minha tia Osmari que me apoiou e não deixou um dia se quer de se preocupar com meu bem durante essa jornada

As minhas cunhadas(os) que sempre me apoiaram e me ajudaram e se dedicaram com cuidados e carinhos aos meus filhos, na minha ausência, para que eu pudesse dar continuidade à esse projeto

À Marilene (Mari) que pude contar com sua dedicação e carinho para com meus filhos na minha ausência, realmente meu braço direito. 


\section{AGRADECIMENTOS}

Tenho muito a agradecer a minha orientadora $D r^{a}$ Maria Helena Catelli de Carvalho, pela incrível oportunidade que me proporcionou ao abrir as portas de seu laboratório e principalmente por ter acreditado na minha capacidade. Agradeço também, pela paciência e compreensão que teve comigo sempre me auxiliando nos momentos mais difícieis.

Poucas pessoas teriam feito o mesmo. Mais uma vez, muito obrigada. 


\section{AGRADECIMENTOS}

À minha coorientadora Dr ${ }^{a}$ Graziela S. Ceravolo (Grabela), que me apoio e se desdobrou, desde o início, me transmitindo o máximo de conhecimentos possíveis, mas principalmente pela paciência e compreensão, que não foram poucas, para lidar com minhas dificuldades. Muito obrigada Grá. 


\section{AGRADECIMENTOS}

Tenho muito que agradecer à DEUS por todas as oportunidades que me enviou, algumas que eu nem acreditava que conseguiria abraçar e realizar, mas ELE realmente nunca me desamparou.

$\mathrm{Na}$ verdade, por mais que eu tente escrever agradecendo a todas as pessoas que conviveram comigo nesse tempo, não conseguirei colocar no papel cada sentimento que tive por aquele que me estendeu a mão, foi solidário e até mesmo afetuoso nas horas mais difícies. Nessa etapa aqui concluida, além de ter me capacitado profissionalmente, mais do que isso, aprendi muito com todos que conheci e convive, são ensinamentos que ficam não só na nossa memória mas em nosso sentimento.

Rosângela, primeira pessoa que conheci na chegada à esse laboratório, além de seu apóio, foi extremamente atenciosa em todos os momentos em que precisei.

Núbia (Nubita) e Fernandinho, sem me conherem, assim que cheguei ao grupo me receberam de braços abertos e ajudaram nos primeiros passos, além de estarem sempre prontos para me apoiar.

Simone, com sua paciência e simplicidade não cansou de me responder as mesmas dúvidas várias vezes, sem contar com o apóio logistico ,sua casa sempre esteve aberta para minhas pernoites em São Paulo. Obrigada por toda sua dedicação.

Cida, amiga e profissional exemplar tanto pelo seu excelente trabalho como, principalmente, por seu carisma e dedicação, por me ajudar em tantos experimentos e ensinar tantas coisas durante todo esse período, foi e é uma grande companheira.

Tiago (Tiaguito), imensurável companherismo e afeto, em nenhum momento esteve longe, tanto fisicamente como em pensamento, sem falar nas trocas de apóio e ajudas técnicas, que foram indispensávies. 
Eveline, sem palavras para descrever o quanto você me ajudou com seu estímulo, apóio, afeto e principalmente por acreditar que eu conseguiria, realmente ganhei uma grande amiga, determinada, organizada (espero chegar perto disso algum dia). Muito obrigada por todos os momentos.

Eli, um exemplo de profissional além de estar sempre pronta á auxiliar.

Gisele, companheira de disciplinas, sempre deixando mais leve as nossas empreitadas, com seu bom humor.

Bia, Cynthia, Vanessa, Grá Neves, André, Andréia, Priscila, Laurinha muito obrigada pelo carinho, amizade e parceria durante todo esse período em que conviviu com vocês, foi maravilhoso.

Às secretárias do departamento de Farmacologia, Selma, Julieta e Camila, pelo apoio, auxílio, amizade e cafés da manhã muito agradáveis.

Aos funcionários do laboratório de hipertensão e diabetes: Ritinha, Martinha, Antônio, Sônia (Ba), Manoel,pela atenção, auxílio e amizade.

Ás meninas do laboratório de sinalização redox: Aline, Ana Alice e Lívia pela ajuda e amizade.

Ao Conselho Nacional de Desenvolvimento Científico e Tecnológico (CNPq) e à Fundação de Amparo à Pesquisa do Estado de São Paulo (FAPESP), pelo auxílio financeiro durante todo esse período do mestrado. À CNPq pelos 6 meses de bolsa e à FAPESP pelos 18 meses de bolsa.

À Dra Zuleica Bruno Fortes por permitir-me que usufruísse de seu laboratório e pela colaboração com sua larga experiência, em nosso projeto.

Aos funcionários da biblioteca do ICB-USP pelas correções e apoio na finalização da dissertação.

A todos que por tanto colaboraram ao longo deste caminho e contribuiram de alguma maneira, em cada etapa, para que eu pudesse realizar este trabalho.

\section{MUITO OBRIGADA DE CORACÃO À TODOS!!!}




\section{RESUMO}

GIAQUINTO, L. R. R. Indução de receptor B1 de cininas em vasos sanguineos de ratos hipertensos por infusão de angiotensina II: estudo molecular e funcional. 2010. 66 f. Dissertação (Mestrado em Farmacologia) - Instituto de Ciências Biomédicas, Universidade de São Paulo, São Paulo, 2011.

O objetivo deste estudo foi avaliar o efeito modulador da infusão de angiotensina II (ANG II) na expressão de RNAm e protéica do receptor B1 (RB1) de cininas em aorta e as arteríolas mesentéricas de ratos Wistar, assim como, estudar o papel deste receptor na pressão arterial e reatividade vascular. Para isso, ratos Wistar com 10 semanas de idade receberam por 28 dias através de uma mini-bomba de infusão osmótica implantada no tecido subcutâneo ANG II [(400ng/ $/ \mathrm{kg} / \mathrm{min})$ grupo ANG II] ou ANG II (400ng/Kg/min) associada ao antagonista de RB1, des-Arg9-Leu8-bradicinina [(350 $\mathrm{ng} / \mathrm{Kg} / \mathrm{min})$ grupo ANG II+ DAL]. Como grupo controle deste modelo foram utilizados ratos da mesma linhagem e idade, submetidos ao mesmo procedimento cirúrgico sem implante da mini-bomba de infusão osmótica. Para confirmar a eficácia da indução da hipertensão arterial por ANG II, a pressão arterial caudal foi aferida em todos os grupos semanalmente, num período de 28 dias, após o implante de mini-bomba de infusão osmótica. A expressão do RNAm e protéica do RB1 foi avaliada através de RT-PCR em tempo real e imunohistoquímica respectivamente. Foi observado que a infusão de ANG II em ratos Wistar causou hipertensão arterial, aumento da expressão de RNAm de RB1 em aorta e arteríolas mesentéricas quando comparadas àquelas do grupo controle. A expressão protéica de RB1 foi detectada em aorta, mas não em arteríolas mesentéricas de ratos ANG II. O agonista de RB1, induziu relaxamento dependente de endotélio e da geração de óxido nítrico em anéis de aorta isolada de rato ANG II, mas não alterou a reatividade de arteríolas mesentéricas estudadas tanto in vivo - in situ quanto in vitro. A hipertensão arterial induzida por ANG II não foi alterada pelo antagonista de RB1. Com o objetivo de avaliar a participação do RB1 na função endotelial de ratos hipertensos, curvas concentração efeito á acetilcolina $(\mathrm{ACH})$, vasodilatador dependente de endotélio, foram construídas em anéis de aorta. Foi observado que a resposta máxima (RMAX) à $\mathrm{ACH}$ foi menor nas preparações isoladas de animais ANG \| e ANG \| + DAL 
quando comparadas àquelas dos ratos Controle, caracterizando assim disfunção endotelial. Embora o desenvolvimento da hipertensão e a disfunção endotelial encontradas nos ratos ANG II não tenham sido corrigidos pelo DAL , a sensibilidade à $\mathrm{ACH}$ medida pelo $\mathrm{pD} 2 \mathrm{e}$ a expressão da eNOS foram maiores no grupo ANG II + DAL quando comparada com as do grupo ANG II. Nossos resultados nos permitem concluir que a ANG II modula a expressão de RB1 na aorta de ratos e que este receptor de cininas pode contribuir para alguns dos efeitos vasculares da ANG II, tal como disfunção endotelial, entretanto, não participa no desenvolvimento da hipertensão arterial causada por este peptídeo. Dessa forma, as interações dos sistemas renina-angiotensina e calicreína-cininas vão além de efeitos antagônicos classicamente descritos, uma vez que componentes destes sistemas podem atuar sinergicamente no desenvolvimento de alterações vasculares nesse tipo de modelo de hipertensão arterial.

Palavras - Chave: Hipertensão arterial. Angiotensina II. Cininas. Receptor B1. 


\section{ABSTRACT}

Giaquinto, L. R. R. Induction of kinin B1 receptor in blood vessels of angiotensin II-hypertensive rats: molecular and functional studies. 2010. 66 p. Masters thesis (Pharmacology) - Instituto de Ciências Biomédicas, Universidade de São Paulo, São Paulo, 2011.

The aim of the present study was to evaluate whether angiotensin II (ANG II) infusion modulates kinin $B 1$ receptor (B1R) mRNA and protein expression in aorta and mesenteric arterioles of the Wistar rats. It was also evaluated blood pressure, aorta and mesenteric arterioles reactivity to RB1 agonist, des-Arg9-bradykinin (DABK). Wistar rats10-weeks old were infused either with ANG II [(400ng/Kg/min),group ANG II] or ANG II (400ng/Kg/min) plus RB1 antagonist, des-Arg9-Leu8-bradykinin [(DAL $350 \mathrm{ng} / \mathrm{Kg} / \mathrm{min}$ ) ,group ANG II + DAL] during 28 days throughout an osmotic minipump subcutaneously. As a control group, Wistar rats at the same age underwent to the same surgical procedure without the mini-pump implantation. The blood pressure was measured weekly, during 28 days, by indirect tail-cuff method.in conscious rats The B1R mRNA and protein expression were assessed by RT-PCR real-time and immunohistochemistry respectively. It was observed that ANG II infusion caused hypertension, increased RB1 mRNA expression in aorta and mesenteric arterioles when compared to the ones in the control group. The RB1 protein expression was detected in aorta, but not in mesenteric arterioles of ANG II rats. We also observed that DABK, B1R agonist, induced endothelium and nitric oxide-dependent relaxation in aortic rings isolated from ANG II rats, but not in mesenteric arterioles studied in vivo - in situ and in vitro. The B1R antagonist did not interfere with the development of hypertension caused by ANG II. To evaluate the role of RB1 in the endothelial function of hypertensive rats, cumulative-concentration effect curves to acetylcholine $(\mathrm{ACH})$, an endothelium-dependent vasodilator, were constructed in aortic rings isolated from ANG II, ANG II + DAL and control rats. It was observed that the maximum response (RMAX) to $A C H$ was decreased in aortas from ANG II and ANG II + DAL rats when compared to control, characterizing endothelial dysfunction. Although the hypertension development and the endothelium dysfunction observed in 
the ANG II rats were not modified by DAL,the sensitivity to $A C H$ and eNOS expression were increased. Our results allow us to conclude that ANG II modulates the expression of $B 1 R$ in aorta of rats and also that B1R may contribute to some of the vascular effects of ANG II, such as endothelial dysfunction. However, this receptor did not participate in the development of hypertension caused by ANG II. Altogether, we may suggest that the ANG II and kinins interactions go further than the opposite effects classically described. In fact, they can act synergistically in the development of vascular changes in this model of arterial hypertension.

Key words: Hypertension. Angiotensin II. Kinins. B1 receptor. 


\section{LISTA DE ILUSTRAÇÕES}

Figura 1. Sistema Renina Angiotesina Aldosterona. 25

Figura 2. Interação Sistema Renina Angiotensina e Calicreína Cinina 27

Figura 3. Receptores B1 e B2 de cininas .28

Figura 4. Evolução da pressão arterial caudal $(\mathrm{mmHg})$ de ratos infundidos com ANG II, através de mini-bomba osmótica implantadas no tecido subcutâneo e de ratos Controle nas semanas 1, 2, 3 e 4 .... .42

Figura 5. Expressão de RNAm de RB1 de cininas realizada em aorta e arteríolas de ratos do grupo controle e do grupo ANG II avaliadas por RT-PCR tempo real.

Figura 6. Curvas concentração-efeito à $D A B K$ obtidas em anéis de aorta com $E+$ e sem E- endotélio isolados de ratos Controle e ANG II.

Figura 7. Curvas concentração-efeito à $D A B K$ obtidas em anéis de aorta com $E+$ isolados de ratos ANG II pré-incubadas ou não com L-NAME 46

Figura 8. Registro típico obtido com a perfusão do leito arteriolar mesentérico de ratos ANG II com NA e com injeção "in bolus" de diferentes concentrações de DABK 46

Figura 9. Registro típico obtido com a perfusão do leito arteriolar mesentérico de ratos Controle com NA e com injeção "in bolus" de diferentes concentrações de DABK

Figura 10. Imagens típicas obtidas no estudo in vivo e in situ de reatividade de arteríolas mesentéricas de ratos ANG II. A) Imagem da medida do diâmetro basal; 
B) Imagem da pré-contração com NA (1 $\mu \mathrm{M})$ 100\% de contração; C) Imagem representativa da aplicação "in bolus" de DABK (1 mM); D) Imagem da medida do diâmetro basal; E) Imagem da pré-contração com NA (1 $\mu \mathrm{M}), 100 \%$ de contração; F) Imagem representativa aplicação "in bolus"de BK $(1 \mu \mathrm{M})$

Figura 11. Expressão protéica e localização do RB1em aorta e ateríolas mesentéricas de ratos: Imagens representativas da imunuhistoquímica para o anticorpo anti-receptor B1 A) em cortes de aorta de ratos ANG II (400 $\mathrm{ng} / \mathrm{Kg} / \mathrm{min})$, B) em cortes de aorta de ratos controle, $\mathrm{C}$ ) em cortes de aorta de ratos (controle negativo), D) em cortes de arteríolas mesentéricas de ratos ANG ॥ (400ng/Kg/min), E) em cortes arteríolas mesentéricas de ratos Controle, F) em cortes de arteríolas mesentéricas de ratos (controle negativo). .49

Figura 12. Evolução temporal da pressão arterial caudal $(\mathrm{mmHg})$ de ratos infundidos com ANG II, ANGII + DAL através de mini-bomba osmótica implantadas no tecido subcutâneo e de ratos Controle nas semanas 1, 2, 3 e 4 .50

Figura 13. Curva concentração-efeito à $\mathrm{ACH}$ obtidas em anéis de aorta com endotélio isolados de ratos ANG II, ANG II + DAL e Controle .51

Figura 14. Valores de pD2 para $\mathrm{ACH}$ em anéis de aorta com endotélio isolados de ratos ANG II, ANG II + DAL e Controle. .52

Figura 15. Valores da resposta máxima para $\mathrm{ACH}$ em anéis de aorta com endotélio isolados de ratos ANG II, ANG II + DAL e Controle, pré-contraídos com fenilefrina $10-6 \mathrm{M}$.

Figura 16. Expressão de RNAm de eNOS verificada em aorta de ratos ANG II, ANG II+ DAL e Controles avaliadas por RT-PCR em tempo real. .53 
Figura 17. Esquema representativo de provável mecanismo de ação. (ANG II) angiotensina II, (AT1) receptor de angiotensina II, (NAD(P)H oxidase) nicotine adenine dinucleotide phosphate na forma reduzida, (DABK) agonista RB1, (DAL) antagonista RB1, (NO) óxido nítrico, (NF-kB) fator de transcrição nuclear,(eNOS) óxido nítrico sintase endotelial, $\left(\mathrm{O}^{-2}\right)$ ânion superóxido, (OONO) peróxinitrito, $\left(\mathrm{H}_{2} \mathrm{O}_{2}\right)$ peróxido de hidrogênio, $\left(\mathrm{H}_{4} \mathrm{~B}\right)$ cofator tetrahidrobiopterin 59 


\section{LISTA DE ABREVIATURAS E SIGLAS}

$\begin{array}{ll}\text { ACH } & \text { Acetilcolina } \\ \text { ANG I } & \text { Angiotensina I } \\ \text { ANG IV } & \text { Angiotensina 3-8 } \\ \text { ANG 1-7 } & \text { Angiotensina 1-7 } \\ \text { ANG II } & \text { Angiotensina II } \\ \text { ANOVA } & \text { Análise de variância } \\ \text { ARB } & \text { Bloqueador receptor de angiotensina } \\ \text { AT1 } & \text { Receptor para Angiotensina II } \\ \text { AT2 } & \text { Receptor para Angiotensina II } \\ \text { B1 } & \text { Receptor de cininas } \\ \text { B2 } & \text { Receptor de cininas } \\ \text { BK } & \text { Bradicinina } \\ \text { CaCl } 2 & \text { Cloreto de cálcio } \\ \text { CCE } & \text { Curva Concentração efeito cumulativa } \\ \text { cDNA } & \text { DNA complementar } \\ \text { CO }{ }_{2-} & \text { Dióxido de Carbono } \\ \text { DABK } & \text { Des-Arg }{ }^{9} \text { BK (bradicinina) } \\ \text { DAL } & \text { Des-Arg-Leu'-BK (bradicinina) } \\ \text { DCV } & \text { Doenças cardiovasculares } \\ \text { DNA } & \text { Ácido Desoxirribonucléico } \\ \text { eNOS } & \text { Oxído nítrico sintase endotelial } \\ \text { (E+) } & \text { Com endotélio } \\ \text { (E-) } & \text { Sem endotélio } \\ \text { DNase } & \text { Enzima digestora de DNA } \\ \text { ECA 2 } & \text { Enzima Conversora de Angiotensina 2 } \\ \text { ECA } & \text { Enzima conversora de Angiotensina } \\ \text { EDHF } & \text { Fator hiperpolarizante derivado de enotélio } \\ \text { EDTA } & \text { Ácido etilenodiaminotetracético } \\ \text { epm } & \text { Erro padrão da média } \\ \text { EROs } & \end{array}$




\begin{tabular}{|c|c|}
\hline $\mathrm{FE}$ & Fenelefrina \\
\hline GAPDH & Enzima gliceraldeído fosfato dehidrogenase \\
\hline $\mathrm{H}_{2} \mathrm{O}_{2}$ & Peróxido de hidrogênio \\
\hline $\mathrm{H} 4 \mathrm{~B}$ & Cofator tetrahidrobiopterin \\
\hline iECA & Inibidor da enzima conversora de Angiotensina \\
\hline $\mathrm{KCL}$ & Cloreto de potássio \\
\hline $\mathrm{KH}_{2} \mathrm{PO}_{4}$ & Fosfato Monopotassico \\
\hline L-NAME & L-nitro arginina metil-éster \\
\hline Lys-BK Calidina & Cinina \\
\hline MAP quinase & Mitogen-activated protein" \\
\hline MAS & Receptor angiotensina 1-7 \\
\hline Met-LysBK & Cinina \\
\hline $\mathrm{MgSO}_{4}$ & Sulfato de magnésio \\
\hline $\mathrm{mmHg}$ & Milímetro de mercúrio \\
\hline NA & Noradrenalina \\
\hline NACL & Cloreto de sódio \\
\hline $\mathrm{NaHCO}_{3}$ & Bicarbonato de sódio \\
\hline \multicolumn{2}{|c|}{$\mathrm{NAD}(\mathrm{P}) \mathrm{H}$ oxidase Fator de transcrição nuclear } \\
\hline$N F-\kappa B$ & Fator de transcrição de kappaB \\
\hline NO & Óxido nítrico, \\
\hline $\mathrm{O}_{2}$ & Oxigênio \\
\hline $\mathrm{OONO}^{-}$ & Peróxinitrito \\
\hline RMAX & Resposta máxima \\
\hline RB1 & Receptor de cininas B1 \\
\hline RB2 & Receptor de cininas B2 \\
\hline PA & Pressão arterial \\
\hline PCR & Reação de polimerase em cadeia \\
\hline pD2 & -LOG [EC 50$]$ \\
\hline PGI2 & Prostaciclina \\
\hline RNAm & Ácido Ribonucléico mensageiro \\
\hline RNase OUT & Inibidor de ribonuclease recombinante \\
\hline RT & Transcriptase reversa \\
\hline
\end{tabular}




$\begin{array}{ll}\text { SCC } & \text { Sistema Calicreína-Cininas } \\ \text { SRA } & \text { Sistema-Renina Angiotensina } \\ \text { SVC } & \text { Sistema Cardiovascular } \\ \text { 2R 1C } & \text { dois rins um clipe } \\ \text { G2 } & \text { dois rins um clipe }\end{array}$




\section{SUMÁRIO}

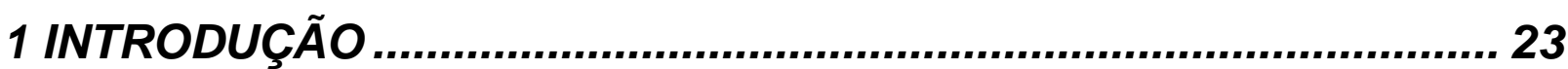

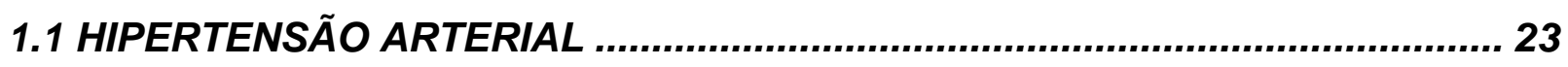

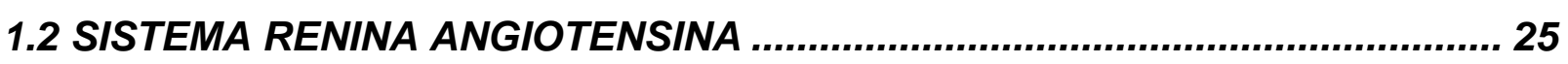

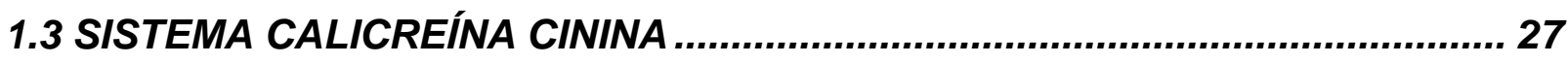

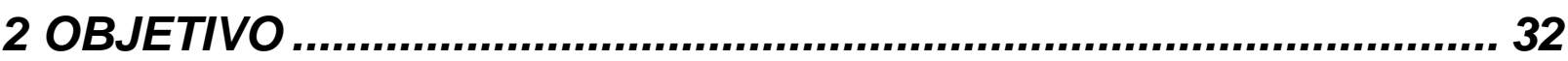

3 DROGAS E REAGENTES E SAIS ............................................................... 33

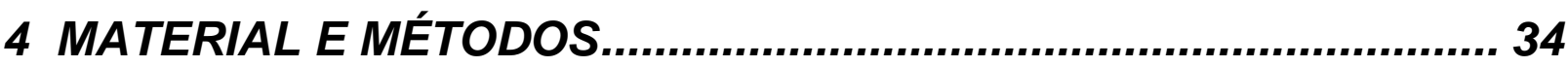

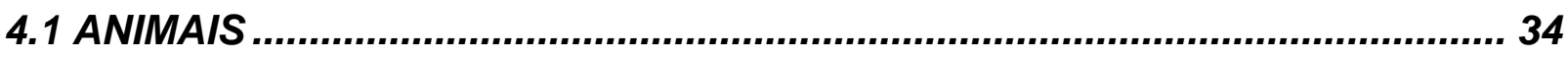

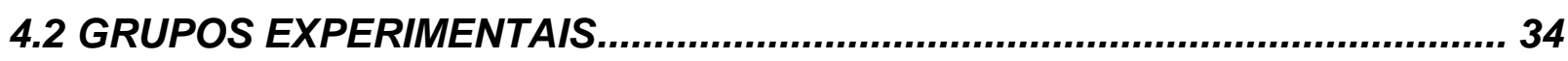

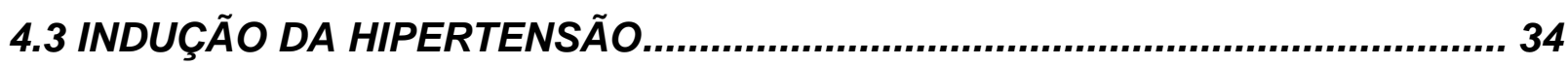

4.4 DETERMINAÇÃO DA PRESSÃO ARTERIAL CAUDAL ................................. 35

4.5 DETERMINAÇÃO DE RNAT DE RB1 EM AORTA E EM ARTERÍOLAS MESENTÉRICAS E DE ENOS EM AORTA DE RATOS POR REAÇÃO DE TRANSCRIPTASE REVERSA E REAÇÃO DE POLIMERASE EM CADEIA EM TEMPO REAL (RT-PCR EM TEMPO REAL) ..................................................... 36

4.6 DETERMINAÇÃO DA EXPRESSÃO PROTÉICA DE RB1 DE CININAS NA AORTA E ARTERÍOLAS MESENTÉRICAS DE RATOS ANG II E CONTROLE...... 37 4.6.1 IMUNOHISTOQUÍMICA ....................................................................3

4.6.2 ANÁLISE DA LOCALIZAÇÃO PROTÉICA DE RB1 DE CININAS NA AORTA TORÁCICA ISOLADA DE RATOS .................................................................. 38

4.7 ESTUDOS FUNCIONAIS..................................................................... 38

4.7.1 ESTUDO in vitro DA REATIVIDADE DE ANÉIS DE AORTA TORÁCICA ISOLADOS DE RATOS............................................................................. 38

4.7.1.1 Avaliação da resposta vasodilatadora ao DABK, agonista $R B 1$......................38

4.7.1.2 Avaliação da participação do óxido nítrico (NO) na resposta à DABK ao agonista de RB1

4.7.1.3 Avaliação da resposta vasodilatadora à $\mathrm{ACH}$ em anéis de aorta dos ratos dos diferentes grupos 39 
4.7.2 ESTUDO in vitro DA REATIVIDADE DO LEITO ARTERIOLAR MESENTÉRICO PERFUNDIDO DE RATO..

4.7.2.1 Avaliação da resposta vasodilatadora ao DABK, agonista de RB1 40 4.7.3 ESTUDO in vivo e in situ DA REATIVIDADE DO LEITO ARTERIOLAR MESENTÉRICO DE RATO 41

4.7.3.1 Avaliação da resposta vasodilatadora ao DABK, agonista de RB1 e ao BK, agonista de RB2 41

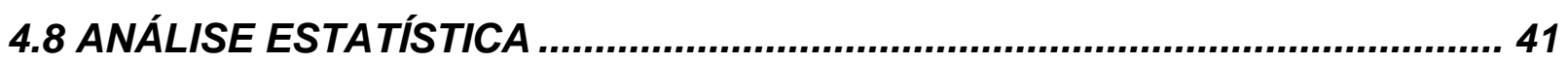

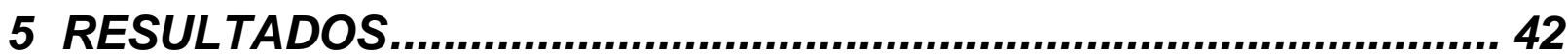

5.1 DETERMINAÇÃo dA PRESSÃo ARTERIAL CAUDAL dE RATOS HIPERTENSOS POR INFUSÃO DE ANG II (400ng/Kg/min) POR 28 DIAS............ 42 5.2 DETERMINAÇÃO DO RNAm DE RB1 EM AORTA E ARTERÍOLAS MESENTÉRICAS DE RATOS ANG II E CONTROLE POR RT-PCR EM TEMPO REAL 43

5.3 ESTUDO DE REATIVIDADE VASCULAR in vitro AO DABK, AGONISTA DE RB1 44

4.3.1 ANÉIS DE AORTA 44

5.3.2 ESTUDO DA REATIVIDADE DE ARTERÍOLAS MESENTÉRICAS PERFUNDIDAS in vitro AO DABK, AGONISTA DE RB1 46

5.3.3 ESTUDO in vivo DA REATIVIDADE DE ARTERIOLAS MESENTÉRICAS AO DABK, AGONISTA DE RB1 E BK, AGONISTA RB2. 48

5.4 DETECÇÃO E LOCALIZAÇÃO DA EXPRESSÃO PROTÉICA DO RB1 EM AORTA E ARTERÍOLAS MESENTÉRICAS DE RATO POR IMUNOHISTOQUÍMICA 49

5.5 DETERMINAÇÃO DA PRESSÃo ARTERIAL CAUDAL DE RATOS INFUNDIDOS COM ANG II (400ng/Kg/min), COM E SEM TRATAMENTO COM (DAL) POR 28 DIAS 50

5.6 REATIVIDADE DE ANÉIS DE AORTA COM ENDOTÉLIO PARA ACH APÓS ANTAGONISMO DO RECEPTOR B1 DAL EM RATOS ANG II 51

5.7 DETERMINAÇÃO DO RNAm POR RT-PCR EM TEMPO REAL DA ENOS EM AORTA DE RATOS. 53 


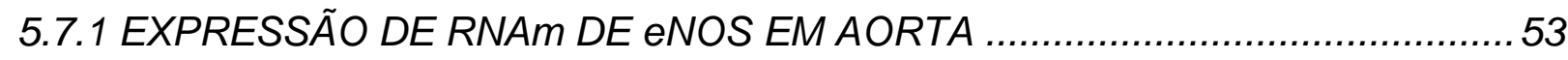

6 DISCUSSÃO ............................................................................. 54

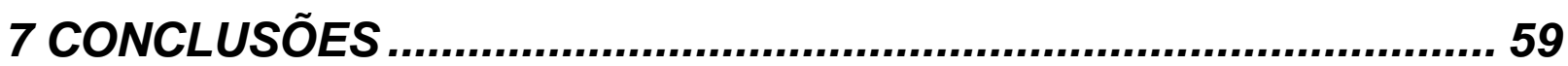

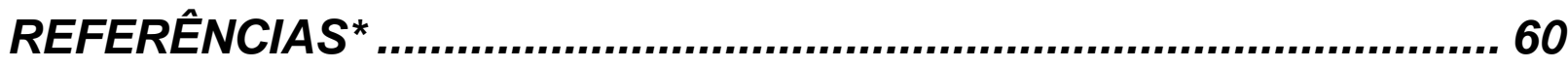




\section{INTRODUÇÃO}

\subsection{HIPERTENSÃO ARTERIAL}

A hipertensão arterial, caracterizada pelo aumento crônico dos níveis pressóricos, é um dos principais fatores de risco para o desenvolvimento de doenças cardiovasculares, o que representa hoje no mundo e no Brasil uma das maiores causas de morte, dessa forma o seu controle é um importante desafio para a saúde mundial (SHARMA, 2009; KEARNEY et al., 2005). O número estimado de adultos no ano 2000 com hipertensão foi de 1 bilhão e a estimativa para 2025 é que tenha um aumento de cerca de $60 \%$, chegando a 1,56 bilhões de adultos hipertensos (KEARNEY et al., 2005). Dessa forma a pesquisa, prevenção, detecção, tratamento e controle desta doença devem receber alta prioridade.

Além do aumento dos níveis pressóricos a hipertensão é caracterizada pelo aumento da resistência periférica ao fluxo sanguíneo, regulada principalmente pelas artérias de resistência. Este aumento da resistência periférica na hipertensão arterial decorre das alterações estruturais processo conhecido como remodelamento vascular, alterações mecânicas e funcionais nas artérias de resistência (SCHIFFRIN, 1992).

O desenvolvimento da hipertensão arterial se dá devido a alterações e interações de vários sistemas como, sistema nervoso autônomo simpático, sistema renal, do sistema renina angiotensina (SRA) e sistema calicreína cinina (SCC) (MARCEAU, 1998), além da disfunção endotelial que acontece por um desequilíbrio da produção e liberação de fatores contráteis e relaxantes derivados do endotélio, células que revestem os vasos sanguíneos (MANO, 2010). São muitos os sistemas e mecanismos que contribuem para regular e manter a pressão arterial constante ao longo da vida do indivíduo.

O sistema nervoso autônomo simpático, por exemplo, está relacionado com os mecanismos responsáveis pela regulação momento a momento da pressão arterial. Essa regulação momento a momento também é denominada regulação a curto e medio prazo e envolvem mecanismos locais, neurais e hormonais. Nos mecanismos neurais os barroceptores, receptores que sinalizam alterações nos diferentes parêmetros funcionais do sistema cardiovascular, são responsáveis por 
essa regulação. Além das respostas neurais, que ocorrem em questão de segundos, os barroceptores controlam também a liberação de vários hormônios (catecolaminas adrenais, angiotensina, vasopressina) que são coadjuvantes na manutenção dos níveis basais de pressão (KRIEGER et al; 1999).

Um importante sistema que participa ativamente da regulação neuro hormonal é o SRA aldosterona, nesse sistema os efeitos da ANG II na regulação cardiovascular são múltiplos e de grande importância, como a ação vasoconstritora direta, aumento da síntese e a liberação de aldosterona, estimulo da ingestão hídrica contribuindo adicionalmente para o aumento da volemia. (MICHELINI LC; 2008)

Diferente do sistema nervoso simpático, o controle da pressão arterial, a longo prazo, é realizado na maior parte pelo rim controlando a volemia pela absorção de sódio e água, e é influenciado pelo sistema renina-angiotensinaaldosterona onde a angiotensina II que produz a vasoconstrição nas arteríolas também é responsável pela estimulação do córtex supra-renal a secretar a aldosterona.

Outro componente que participa no controle da pressão aterial, a longo prazo, é o hormônio antidiurético, que regula a osmolaridade do sangue e o volume circulante. Dessa forma podemos concluir que as alterações nesses mecanismos e sistemas, implicados na regulação cardiovascular, podem resultar direta ou indiretamente, em diversas doenças cardiovasculares.

O SRA quando ativado crônicamente desempenha um papel importante no desenvolvimento de várias doenças cardiovasculares (DCV). Neste contexto, a inibição do SRA tem sido eficaz no tratamento farmacológico da hipertensão. Este tratamento envolve três classes de fármacos: bloqueadores dos receptores de angiotensina II (ARB), os inibidores da renina e inibidores da enzima conversora da angiotensina (iECA) (CZARINA ACELAJADO et al., 2009).

Recentemente, vem sendo descrito em estudos clinicos que os efeitos protetores sobre o sistema cardiovascular (SCV) de indivíduos hipertensos, observados com a inibição da enzima conversora de angiotensina (ECA), envolvem, além da redução da formação de ANG II, o aumento do tempo de meia-vida de componentes do SCC, as cininas, confirmando então a relevância do SCC na manutenção da homestase cardiovascular (DUKA et al., 2008). 


\subsection{SISTEMA RENINA ANGIOTENSINA}

O SRA exerce um papel importante no controle da pressão arterial (GUYTON; HALL, 2002).

A diminuição da pressão arterial estimula a síntese de renina pelas células justaglomerulares e sua liberação na corrente sanguínea. No sangue, a renina atua sobre o angiotensinogênio, globulina liberada pelo fígado, formando a angiotensina I (ANG I) decapeptídeo que, sob ação da ECA, transforma-se em ANG II, que executa diversas ações fisiológicas e fisiopatológicas através de seus receptores, uma delas é a estimulação da secreção de aldosterona do córtex adrenal (GUYTON; HALL, 2002), como mostra de forma representativa a figura 1.

A ANG II é o principal peptídeo efetor do SRA, desempenhando papel fundamental no controle da pressão arterial e equilíbrio eletrolítico (TOUYZ et al., 2000).

Como já citado, ações biológicas da ANG II acontecem pela interação com receptores acoplados à proteína $G$, classificados como AT1, AT2, AT3 e AT4. A maioria das ações fisiológicas da ANG II incluindo vasoconstrição, estimulação da secreção de aldosterona, retenção de sal e água e crescimento celular são mediadas pelo receptor AT1 que é expresso na maioria das células incluindo as de vasos sanguíneos, coração, adrenal, rins e pulmões (SILVERSTEIN et al., 2004; SCHIFFRIN et al., 2002). Já o receptor AT2 parece ter efeitos opostos aos da ativação do AT1, como por exemplo, vasodilatação, inibição do crescimento celular, da diferenciação celular e apoptose (WAGENAAR et al., 2002; SCHIFFRIN et al., 2002). 


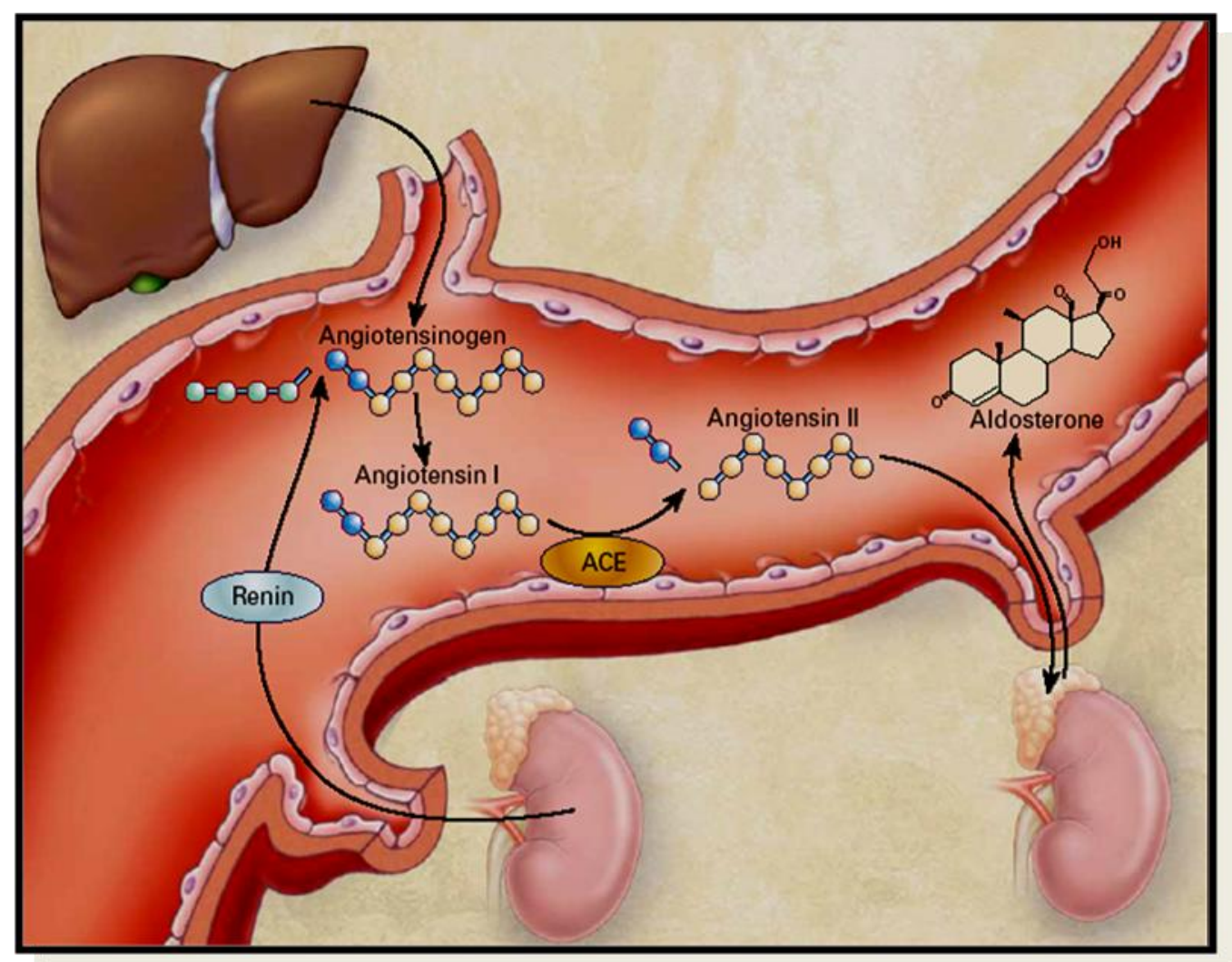

Figura 1. Sistema Renina Angiotensina Aldosterona Fonte: Ribeiro e Plavink (2007).

Apesar da expressão do receptor AT2 em tecidos embrionários ser bastante pronunciada, em tecidos adultos é reduzida quando comparada com a expressão de receptor AT1. Algumas doenças como isquêmica de coronária, cardiomiopatia e fibrilação atrial parecem estar relacionadas com aumento da expressão de receptores AT2, que junto com o antagonismo do receptor AT1, pode ter efeito benéfico sobre essas patologias (FERRARIO et al., 2006).

Vem sendo descritos também outros peptídeos ativos no SRA como, por exemplo, os fragmentos Angiotensina (1-7) (Ang 1-7), Angiotensina (3-8) (Ang IV). Dentre estes o mais estudado é a Ang 1-7 que pode ser formada pela ação da prolil endopeptidase neutra, que cliva a Ang I liberando a Ang 1-7, ou então por ação da enzima conversora de angiotensina II (ECA 2) que cliva a ANG II e libera a Ang 1-7, cujas ações biológicas como vasodilação, natriurese, diurese e efeito anti-trófico acontecem pela interação com receptor acoplado a proteína G chamado de MAS (ABDÜL et al., 1994; SANTOS et al., 1994; SANTOS et al., 2003). Além das ações fisiológicas da ANG II sobre o sistema cardiovascular este peptídeo também está 
envolvido com diversas moléstias que acometem o sistema cardiovascular, como hipertensão, aterosclerose e insuficiência cardíaca.

\subsection{SISTEMA CALICREÍNA CININA}

Um outro componente bastante importante no controle das funções cardiovasculares e ainda na modulação do SRA é o SCC.

No SCC as enzimas denominadas calicreínas (plasmática e tecidual) clivam os cininogênios, produzidos pelo fígado, liberando as cininas: bradicinina (BK), calidina (Lys-BK) e Met-Lys-BK.

Os efeitos biológicos exercidos por esses peptídeos duram poucos segundos, devido à sua rápida metabolização por enzimas denominadas cininases. A principal via de metabolização de BK e Lys-BK decorre da ação da cininase II ou ECA pela remoção do dipeptídeo C-terminal, tornando-as inativas (ERDÖS, 1975). Além disso, tanto BK quanto Lys-BK podem ser metabolizadas por outras enzimas, denominadas cininases I (carboxipeptidase $\mathrm{N}$ e M), originando os fragmentos bioativos des-Arg ${ }^{9}$ BK e Lys-des-Arg ${ }^{9}$-BK, que por sua vez, são também inativados pela ECA. (Figura 2)

\section{INTERAÇÃO DOS SCC E SRA}

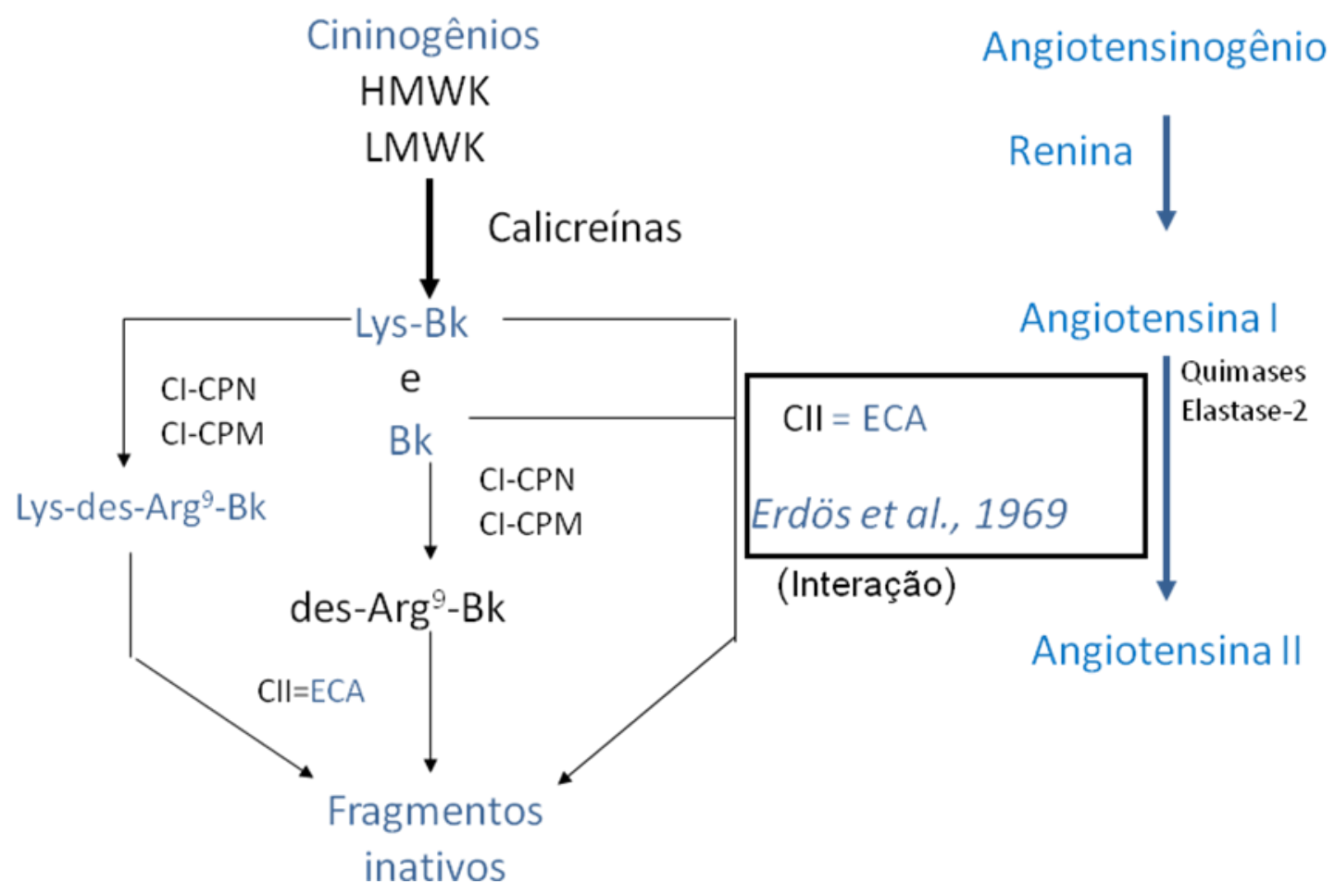

Figura 2. Interação Sistema Renina Angiotensina e Calicreína Cinina. 
As diferentes ações biológicas das cininas são mediadas por dois tipos de receptores, pertencentes à superfamília de receptores acoplados à proteína $\mathrm{G}$ com 7 domínios transmembrânicos, classificados como B1 (RB1) e B2 (RB2). Esses receptores têm sido amplamente estudados e caracterizados, através de sua afinidade pelas diferentes cininas e seus metabólitos, por meio de farmacologia clássica (REGOLI; BARABE, 1980), ensaios de binding em tecidos humanos (HESS et al., 1992; SCHNECK et al., 1994) e por preparações in vivo (BHOOLA et al., 1992; LINZ et al., 1995). Os RB1 e RB2 diferem significativamente no que se refere às respostas induzidas pelas diferentes cininas, sendo o RB2 ativado por BK e Lys-BK e o RB1 sensível aos peptídeos des-Arg ${ }^{9}$-BK (DABK) e Lys-des-Arg ${ }^{9}$-BK (MARCEAU, 1995). (Figura 3).

$B_{1}$ Receptor

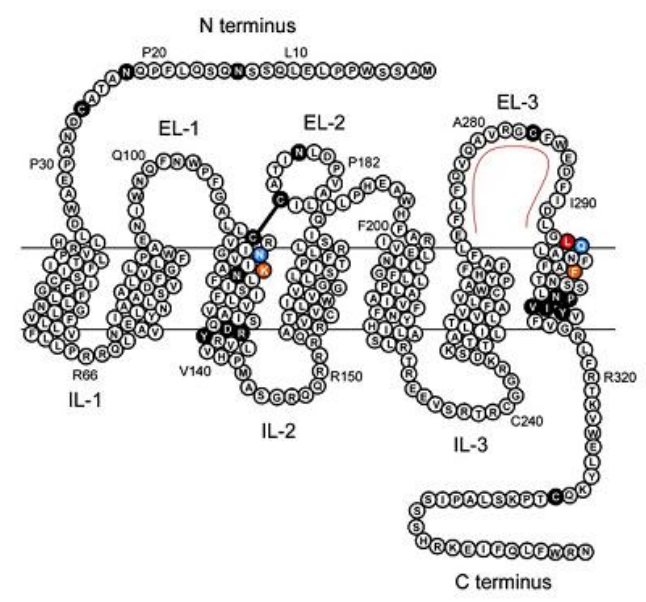

$\mathrm{B}_{2}$ Receptor

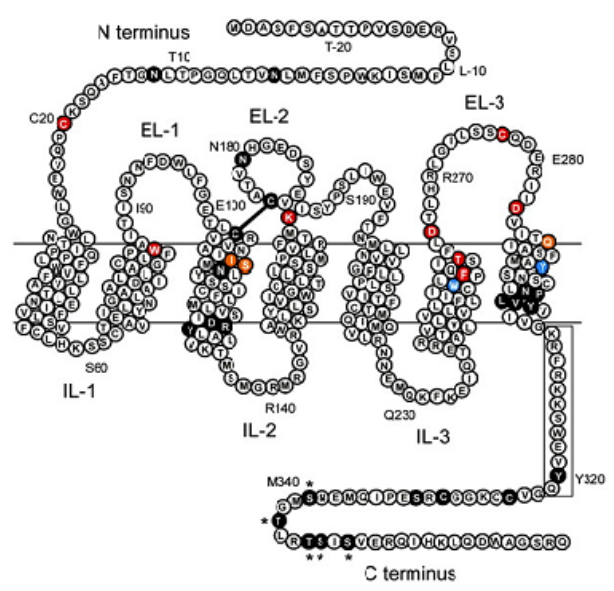

Figura 3. Receptores B1e B2 de Cininas.

O RB2 é expresso constitutivamente em diferentes tecidos, incluindo endotélio vascular, músculo liso vascular e cardiomiócitos. A participação do RB2 no controle de funções cardiovasculares está bem documentada. Os trabalhos descrevem uma vasodilatação mediada por liberação de óxido nítrico (NO), prostaciclina (PGI2) e fator hiperpolarizante derivado do endotélio (EDHF), hipotensão e proteção cardíaca (BHOOLA et al., 1992; BUSSE; FLEMING, 1996; LINZ et al., 1995). Com o desenvolvimento de técnicas de biologia molecular e geração de animais knockout, demonstrou-se que a deleção genética de RB2 em camundongos promove aumento de sensibilidade ao sal e aumento de pressão arterial (MADDEDU et al., 1997), além de remodelamento ventricular e prejuízos funcionais ao coração (EMANUELI et al., 1999). 
O RB1 não é detectado em tecidos em condições normais, mas é rapidamente induzido em situações de injúria tecidual e inflamação (MARCEAU, 1995). Classicamente define-se que a indução de RB1 é realizada por uma série de citocinas presentes no contexto inflamatório, mas vários estudos comprovaram a influência de outros fatores, como proteínas da família MAP quinase ("mitogenactivated protein") (LARRIVÉ et al., 1998), o próprio agonista B1 (SCHANSTRA et

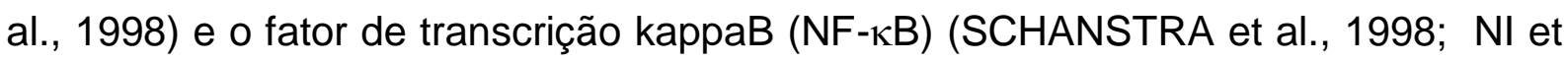
al., 1998; CERAVOLO et al., 2007). A indução de RB1 no SCV vem sendo descrita após infarto do miocárdio na circulação coronária (MC LEAN et al., 1999; DRUMMOND et al., 1995; PRUNEAU et al., 1996) e fibras simpáticas cardíacas (FOUCART et al., 1997), e em modelos de hipertensão em miócitos cardíacos e aorta de ratos (FERNANDES et al., 2006; CERAVOLO et al., 2007). Em vasos sanguíneos, como a aorta, sua estimulação promove relaxamento dependente do endotélio, geralmente relacionada à produção de GMPc (WOHLFART et al., 1997) e liberação de NO (SU et al., 2000; CERAVOLO et al., 2007).

Além disso, alguns autores sugerem o envolvimento de RB1 na patogênese da hipertensão em animais geneticamente hipertensos (EMANUELI et al., 2002; QUADRI et al., 2002), mas a regulação da pressão arterial em condições normais parece independer desses receptores, já que camundongos knockout para RB1 não apresentam alterações significativas dos valores pressóricos (PESQUERO et al., 2000). Entretanto, pouco se sabe sobre a importância desse receptor em situações de estímulo hipertensivo, como por exemplo, durante a infusão de ANG II.

Tem sido sugerida uma importante participação da ANG II na modulação da expressão de RB1 em órgãos do SCV. Estudos mostraram aumento da expressão de RB1 em camundongos e ratos com hipertensão renal [2 rins-1 clip (2R 1C)], modelo caracterizado por altos níveis plasmáticos de renina e ANG II, sugerindo a importância do SRA na modulação da expressão de RB1 de cininas.(FERNANDES, 2006).

Funcionalmente os efeitos dos SCC e SRA se opõem. Entretanto, as interações desses dois sistemas são complexas e nem sempre relacionadas apenas a efeitos antagônicos. Por exemplo, a ANG II conhecida por ser um potente vasoconstritor, via receptor AT1, pode ativar a produção de prostaglandinas por vias 
de sinalização intracelulares de forma semelhante à BK, via RB2 (LINZ et al., 1995; TSCHÖPE; GOHLKE; ZHU, 1997; DENDORFER; WOLFRUM; DOMINIAK, 1999).

Um dos pontos de interação entre SCC e SRA melhor caracterizado é a enzima ECA ou Cininase II que é responsável pela formação da ANG II a partir da ANG I e também degrada as cininas bioativas. Dessa forma, todas as ações das cininas relacionadas ao SCV têm adquirido especial importância devido à ampla utilização de (iECA) na terapia antihipertensiva, pois esses fármacos além de reduzirem a formação de ANG II, o principal agente hipertensor do SRA, também potencializa os efeitos mediados por cininas endógenas (LINZ et al., 1995). Inúmeros estudos demonstraram a importância da ativação de RB2 nessa potencialização de efeitos, comprovando sua contribuição decisiva para as ações cardioprotetoras dos (iECA) (GOHLKE et al., 1994; SCHÖLKENS, 1996), incluindo a inibição de hipertrofia vascular e miocárdica, inibição de remodelamento e fibrose cardíaca, redução da área afetada após o infarto do miocárdio (LINZ et al., 1995), além de contribuir para a melhora de função e metabolismo energético cardíaco (ITO et al., 1997).

Além do acúmulo de BK a inibição de ECA promove também aumento dos níveis do peptídeo DABK (DECAIRE et al., 1996; BLAIS Jr. et al., 1997), principal agonista de RB1. Recentemente foi descrito que inibidores de ECA podem ativar diretamente RB1 em culturas de endotélio vascular ou em células transfectadas com cDNA para receptores B1, resultando em aumento de cálcio intracelular e produção de NO (IGNJAVOTIC et al., 2002). Além disso, Marin-Castaño et al. (2002) demonstraram que a inibição da ECA induz aumento nos níveis de RNAm para RB1 em rim, vasos e coração de ratos e que o bloqueio farmacológico desses receptores causa reversão do efeito sobre a pressão arterial de animais tratados com esses inibidores. Sabendo-se que a própria ativação de RB1 pode induzir sua expressão, o aumento nas concentrações de DABK decorrente da inibição de ECA poderia ser o responsável por essa indução (SCHANSTRA et al., 1998).

O fato de o RB1 ser induzido por moléculas relacionadas com o processo inflamatório como IL-6 e TNF- $\alpha$ está bem documentado (MARCEU et al., 1998) e vem sendo descrito que a ANG II, por atuar como um agente pró-inflamatório, pode modular a expressão de RB1 em órgãos do SCV. De fato, foi demonstrado em culturas de músculo liso vascular de ratos que a incubação com ANG II induziu a 
expressão gênica de RB1 e esse efeito foi bloqueado pelo antagonista de receptores AT1 de ANG II, losartan (KINTSURASHIVILI et al., 2001).

Recentemente em nosso laboratório demonstrou-se que a infusão de ANG ॥ (400 $\mathrm{ng} / \mathrm{kg} / \mathrm{min}$ por 14 dias) induz a expressão de RB1 na aorta de ratos Wistar e que esta indução está relacionada com a geração de espécies reativas de oxigênio e com ativação do NF-kB neste vaso (CERAVOLO et al., 2007). Entretanto, com este protocolo de infusão de ANG II não foi possível observar a expressão de RB1 em órgãos relacionados com o controle da pressão arterial, como, rins e arteríolas mesentéricas. Dessa forma, tivemos como objetivo nesse trabalho, aumentar o tempo de infusão de ANG II (400ng/ $\mathrm{kg} / \mathrm{min})$ por 28 dias em ratos Wistar, para investigar a expressão protéica do RB1 e sua funcionalidade em outro leito vascular como, por exemplo, em arteríolas mesentéricas responsáveis pelo controle da pressão arterial. 


\section{OBJETIVO}

O objetivo deste estudo foi caracterizar o modelo de hipertensão por infusão de ANG II por 28 dias e avaliar o efeito modulador da infusão de ANG II na expressão de RNAm e localização protéica do RB1 de cininas, em aorta e em arteríolas mesentéricas de ratos Wistar.

Como objetivos específicos avaliamos os seguintes parâmetros:

* Reatividade vascular ao agonista de RB1, DABK, em aortas in vitro e arteríolas mesentéricas in vitro e in vivo-in situ de ratos que receberam infusão de ANG I;

* Estudo do antagonismo de RB1 sobre a função endotelial na aorta de ratos que receberam infusão de ANG II;

* Estudo do antagonismo de RB1 sobre a pressão arterial de ratos hipertensos; 


\title{
3 DROGAS E REAGENTES
}

\author{
Acetilcolina - Bachem Group \\ Angiotensina II - Bachem Group \\ Bradicinina - Bachem Group \\ Des-Arg ${ }^{9}$-Bk - Bachem Group \\ Des-Arg ${ }^{9}$ Leu $^{8}$-Bk - Bachem Group \\ Desipramina - Sigma Aldrich \\ Enalaprilato - Sigma Aldrich \\ Fenilefrina - Sigma Aldrich \\ L-NAME - Sigma Aldrich \\ DAB - Sigma Aldrich \\ Noradrenalina - Sigma Aldrich \\ Anticorpo anti receptor B1 de cininas - (lgG policlonal de coelho anti-rato e \\ camundongo) - Santa Cruz Biotechnology \\ Anticorpo secundário conjugado a biotina - Vector Laboratories \\ KIT ABC Vectastain - Vector Laboratories \\ Peróxido de hidrogênio - Merck S/A, Ind. Química
}

\section{Sais}

Os sais utilizados na preparação dos tampões foram adquiridos da Merck S/A, Ind. Química. 


\section{MATERIAL E MÉTODOS}

\subsection{ANIMAIS}

Foram utilizados ratos Wistar com 10 semanas de idade, provenientes do Biotério Central e mantidos no Biotério de Hipertensão do Departamento de Farmacologia do Instituto de Ciências Biomédicas da Universidade de São Paulo. Os ratos tiveram livre acesso à água e ração e foram mantidos em sala com temperatura e umidade constantes $\left(24{ }^{\circ} \mathrm{C} / 60 \%\right.$ ), com ciclos claro/escuro de 12/12 horas. Todos os procedimentos utilizados foram aprovados pela Comissão de Ética de Experimentação Animal do ICB-USP e estavam de acordo com os Princípios Éticos na Experimentação Animal, adotado pelo Colégio Brasileiro de Experimentação Animal (COBEA).

\subsection{GRUPOS EXPERIMENTAIS}

ANG II - Ratos Wistar tornados hipertensos por infusão de ANG ॥ (400 $\mathrm{ng} / \mathrm{kg} / \mathrm{min})$, durante 28 dias, através de mini-bomba de infusão osmótica implantada no tecido subcutâneo do dorso dos animais - Alzet, 2002.

ANG II +DAL: Ratos Wistar que receberam simultaneamente, infusão de ANG II (400ng/Kg/min) e de antagonista de receptor B1 des-Arg ${ }^{9}$-Leu ${ }^{8}$-bradicinina (DAL) (350 $\mathrm{ng} / \mathrm{Kg} / \mathrm{min}$ ) (CERAVOLO et al., 2007) durante 28 dias, através de duas minibombas de infusão osmótica implantada no tecido subcutâneo do dorso dos animais - Alzet, 2002.

Controle: Ratos Wistar que foram submetidos à mesma cirurgia que os demais grupos, porém não receberam o implante da mini-bomba de infusão osmótica, utilizados 28 dias após a cirurgia.

\subsection{INDUÇÃO DA HIPERTENSÃO}

Para o procedimento de indução de hipertensão através da infusão de ANG II, inicialmente os ratos foram anestesiados com cloridrato de Xilasina $(7,4 \mathrm{mg} / \mathrm{Kg}$ de 
peso, ip) e cetamina (113 mg/Kg de peso, ip). Em seguida uma incisão de aproximadamente um centímetro foi feita no dorso dos animais e implantada, no tecido subcutâneo, uma mini-bomba de infusão osmótica de 28 dias - Alzet, 2002, com velocidade de liberação de $0,25 \mu \mathrm{L} / \mathrm{hora}$, preenchida com ANG II (400ng/ $/ \mathrm{gg} / \mathrm{min})$ diluída em salina 0,9\% estéril (grupo de ANG II, $n=12$ ).

Para determinação da participação do RB1 na hipertensão causada pela ANG II um grupo de ratos recebeu implante de duas bombas de infusão, uma preenchida com ANG II $(400 \mathrm{ng} / \mathrm{Kg} / \mathrm{min})$ e outra com antagonista de RB1 $(350 \mathrm{ng} / \mathrm{Kg} / \mathrm{min})$. Como controles foram utilizados ratos da mesma linhagem e idade que foram submetidos ao mesmo procedimento cirúrgico, mas não receberam implante da mini-bomba de infusão (grupo controle $n=12$ ). Após a cirurgia os ratos foram mantidos em gaiolas individuais.

\subsection{DETERMINAÇÃO DA PRESSÃO ARTERIAL CAUDAL}

A pressão arterial caudal foi determinada por método indireto denominado pletismografia de cauda. Para que os níveis pressóricos dos ratos não alterassem devido a manipulação dos mesmos, primeiramente adaptamos os animais ao procedimento que envolvia o aquecimento dos animais em estufa especial por 10 minutos, a $40{ }^{\circ} \mathrm{C}$ e posterior contenção em cilindro de acrílico com abertura para o focinho e cauda, por cinco minutos.

Os níveis pressóricos foram determinados antes do procedimento cirúrgico (semana zero) e semanalmente após o implante das mini-bombas de infusão (semana 1, 2, 3 e 4). Para tanto, os ratos foram aquecidos por 10 minutos a $40{ }^{\circ} \mathrm{C} \mathrm{e}$ colocados no cilindro de contenção. Um oclusor e um sensor foram ajustados à porção proximal da cauda do rato, acoplados ao esfigmomanômetro elétrico PE-399 e conectados a um sistema de transdução (PowerLab, AD Instruments, Melbourne, Austrália). O valor final da pressão arterial caudal de cada animal representa a média aritmética de três medidas seqüenciais e estão expressos em mmHg. 


\subsection{DETERMINAÇÃO DE RNAm DE RB1 EM AORTA E EM ARTERÍOLAS MESENTÉRICAS E DE eNOS EM AORTA DE RATOS POR REAÇÃO DE TRANSCRIPTASE REVERSA E REAÇÃO DE POLIMERASE EM CADEIA EM TEMPO REAL (RT-PCR EM TEMPO REAL)}

Os ratos foram anestesiados com pentobarbital sódico $(500 \mathrm{mg} / \mathrm{Kg}$, i.p.) e após este procedimento a aorta e arteríolas mesentéricas, foram removidas, dissecadas, congeladas em nitrogênio líquido e armazenadas a $80{ }^{\circ} \mathrm{C}$. O RNA total foi isolado utilizando o reagente Trizol $^{\circledR}$ (Invitrogen Co. USA), seguindo as orientações do fabricante. Foi utilizada DNase I para digerir o DNA, que ocasionalmente poderia estar presente na amostra de RNA após o processo de extração. Foi realizada a síntese da fita simples de cDNA por reação de RT, a partir de $2 \mu \mathrm{g}$ do RNA total, utilizando a enzima SuperScript II, e inibidores de RNase para proteger o RNA da metabolização por RNases durante a reação.

A amplificação do cDNA foi realizada utilizando os seguintes oligonucleotídeos:

RB1: sense CCA GGG TTC GTC ATC ACT ATC TG e anti-sense - GCA AAA GGA AGA AGG ACA AGA CTA A;

eNOS: sense TTC TGG CAA GAC CGA TTA CAC GAC AT e anti-sense AAA GGC GGA GAG GAC TTG TCC AAA.

GAPDH: sense GGG CAG CCC AGA ACA TCAT e anti-sense CCG TTC AGC TCT GGG ATGAC

A quantidade de cDNA foi analisada por RT-PCR em tempo real utilizando o reagente Platinum ${ }^{\circledR}$ SYBR $^{\circledR}$ green qPCR SuperMix UDG (Invitrogen). As reações de PCR foram realizadas e analisadas utilizando o sistema Corbett Research (Corbett Life Sciences, Australia).

As condições de PCR utilizadas para amplificação de RNAm para RB1, eNOS e GAPDH foram as seguintes: $2 \mathrm{~min}$ a $95{ }^{\circ} \mathrm{C}$, seguindo de 40 ciclos: $95^{\circ} \mathrm{C}$ por $15 \mathrm{~s}$, $65^{\circ} \mathrm{C}$ por $1 \mathrm{~min}$ e $72{ }^{\circ} \mathrm{C}$ por $20 \mathrm{~s}$. A especificidade da reação com SYBR ${ }^{\circledR}$ green foi confirmada pela análise da curva de dissociação tomando como base a temperatura de dissociação - "melting point". A expressão gênica foi quantificada utilizando o cálculo do $2^{\Delta C T}$. "cycle threshold", como descrito por Pfaffl (2001). O cDNA sintetizado a partir do mRNA do GADPH foi utilizado para normalização. Os 
resultados foram demonstrados como a expressão de RNAm de interesse normalizada pela expressão de RNAm do GAPDH.

\subsection{DETERMINAÇÃO DA EXPRESSÃO PROTÉICA DE RB1 DE CININAS NA AORTA E ARTERÍOLAS MESENTÉRICAS DE RATOS ANG II E CONTROLE}

Os animais foram anestesiados com solução de hidrato de cloral $(200 \mathrm{mg} / \mathrm{Kg}$ i.p.) e após laparotomia o mesentério e aorta foram removidos. As arteríolas mesentéricas e a aorta foram dissecadas e imersas em solução fixadora paraformaldeído 4\% (PFA 4\%) por seis horas. Após a fixação os tecidos foram crioprotegidos em solução de sacarose $30 \%$, por vinte quatro horas, emblocados em meio para congelamento (Leica Instruments), congelados em gelo seco e mantidos a $-70{ }^{\circ} \mathrm{C}$. Para garantir que os cortes usados abrangessem uma porção significativa dos tecidos foram feitos dez cortes não seriados de $10 \mu \mathrm{m}$, a $-25{ }^{\circ} \mathrm{C}$ em criostato Leica CM 1850 (Leica Instruments). Os cortes foram colocados em lâminas com poliL-Lisina (Sigma-Aldrich).

\subsubsection{IMUNOHISTOQUÍMICA}

Os anticorpos primários anti-receptor B1 foram diluídos em tampão fosfato (fosfato de sódio monobásico anidro $0.10 \mathrm{mM}$; fosfato de sódio dibásico anidro 0.10 $\mathrm{mM}$ (PB), $\mathrm{pH} 7.4$ contendo $0,3 \%$ de Tween 20 ) e $5 \%$ de soro normal de coelho na proporção de 1:50 e colocados sobre os cortes de aorta e arteríolas mesentéricas para incubação por um período de aproximadamente dezoito horas a $4{ }^{\circ} \mathrm{C}$. Paralelamente foram realizadas reações controle substituindo o anticorpo primário por PB 0,1M contendo 0,3\% Tween 20 e 5\% de soro normal de coelho.

Após 18 horas, os cortes de aorta e arteríolas mesentéricas foram lavados em PB e incubados com anticorpo secundário conjugado a biotina (Vector Laboratories USA), na diluição 1:1000 por uma hora, em câmara úmida, à temperatura ambiente. Após a incubação os cortes de aorta e arteríolas mesentéricas foram novamente lavados em PB e incubados, em câmara úmida com solução do kit ABC Vectastain (Vector Laboratories - USA) por uma hora, à temperatura ambiente. Após esse período, os cortes foram lavados em PB. 
A revelação da imunoreatividade foi realizada com diaminobenzidina (DAB) 0,5mg/1 mL, e $\mathrm{H}_{2} \mathrm{O}_{2}, 0,06 \%$. Os cortes foram lavados com $\mathrm{PB}$ e água destilada e após as lavagens foram desidratados em álcool, lavadas com xilol e as lâminas foram montadas em Permount ${ }^{\circledR}$ (Fisher Chemical).

\subsubsection{ANÁLISE DA LOCALIZAÇÃO PROTÉICA DE RB1 DE CININAS NA AORTA TORÁCICA ISOLADA DE RATOS}

As análises da imunoreatividade das aortas e arteríolas mesentéricas ao anticorpo anti-receptor B1 foram realizadas em microscópio óptico equipado com uma câmera fotográfica utilizando-se uma objetiva com aumento de 40x. As análises foram determinadas em pelo menos cinco cortes do mesmo órgão, utilizando quatro aortas e arteríolas mesentéricas por grupo experimental. A imagem mais representativa da localização dos receptores B1 de cininas foi escolhida.

\subsection{ESTUDOS FUNCIONAIS}

\subsubsection{ESTUDO in vitro DA REATIVIDADE DE ANÉIS DE AORTA TORÁCICA ISOLADOS DE RATOS}

\subsubsection{Avaliação da resposta vasodilatadora ao DABK, agonista RB1}

Após 28 dias do procedimento cirúrgico os ratos ANG II e controle foram anestesiados com hidrato de cloral $(200 \mathrm{mg} / \mathrm{Kg}$, i.p.), e após toracotomia a aorta torácica foi removida e rapidamente imersa em solução nutriente Krebs-Henseleit modificada. A aorta foi dissecada, os tecidos conectivo e adiposo foram removidos e em seguida cortada em anéis transversais de $4 \mathrm{~mm}$. Em um desses anéis o endotélio foi mantido intacto e no outro foi removido mecanicamente com uma haste fina com algodão. Os anéis com $(E+)$ e sem ( $E-)$ endotélio foram suspensos por um par de ganchos de aço inoxidável. Um gancho foi fixado à base da cuba de vidro para estudo de órgão isolado, e o outro conectado a um transdutor de sinal (ML T001 transdutor isométrico de tensão, Power Lab/8S, ADInstruments Pty Ltda, 
Austrália) acoplado a um computador. As cubas de vidro continham $15 \mathrm{~mL}$ de solução de Krebs-Henseleit modificada cuja composição (em mmol/L) foi: $\mathrm{NaCl}, 113$; $\mathrm{KCl}, 4,7 ; \mathrm{CaCl}_{2}, 2,5, \mathrm{NaHCO}_{3}, 25 ; \mathrm{MgSO}_{4}, 1,1 ; \mathrm{KH}_{2} \mathrm{PO}_{4}, 1,1 ; \mathrm{EDTA}, 0,03$; glicose, 5,$5 ; \mathrm{pH} 7,4$, saturada com mistura de $95 \%$ de $\mathrm{O}_{2}$ e $5 \%$ de $\mathrm{CO}_{2}$ e mantida aquecida a temperatura de $37 \pm 0,5{ }^{\circ} \mathrm{C}$ durante todo o protocolo experimental. As preparações permaneceram sob tensão de $1,5 \mathrm{~g}$ por um período de 60 minutos para estabilização, com trocas de solução nutriente e ajuste de tensão a cada 20 minutos. Em seguida, os anéis de aorta foram incubados com enalaprilato $(10 \mu \mathrm{M})$, inibidor da ECA (iECA), por 30 minutos, para impedir a degradação da cinina. Após este período os anéis de aorta foram pré-contraídos com fenilefrina ( $F E-0,1 \mu \mathrm{M}$ ), concentração que induz tensão equivalente a 60-80\% da tensão máxima induzida por esse agonista, e foram realizadas curvas concentração-efeito cumulativas (CCE) ao agonista de RB1, DABK $(0,1 \mathrm{nM}$ a $1 \mu \mathrm{M})$. O relaxamento induzido pela DABK foi expresso em porcentagem de relaxamento em relação à contração obtida com a FE. Ao final da CCE para DABK os anéis de aorta foram incubados com FE $(0,1 \mu \mathrm{M})$ e posteriormente a acetilcolina $(\mathrm{ACH})(10 \mu \mathrm{M})$ foi adicionada à cuba para verificar a integridade do endotélio. $O$ endotélio foi considerado íntegro quando está concentração de $\mathrm{ACH}$ promoveu pelo menos $60 \%$ de relaxamento.

4.7.1.2 Avaliação da participação do óxido nítrico (NO) na resposta à DABK ao agonista de RB1

Para determinar se o óxido nítrico estaria envolvido na vasodilatação induzida pela $\mathrm{DABK}$ em anéis de aorta, as preparações foram incubadas com a L-nitro

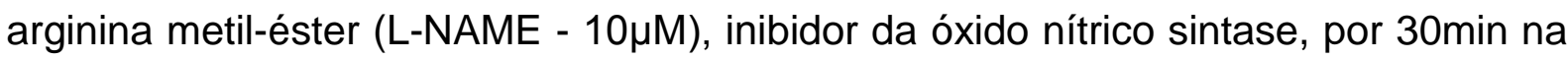
presença de iECA $(10 \mu \mathrm{M})$. Após este período os anéis de aorta foram pré contraídos com FE $(0,1 \mu \mathrm{M})$ e CCE para o DABK $(0,1 \mathrm{nM}$ a $1 \mu \mathrm{M})$, agonista RB1, foi realizada.

4.7.1.3 Avaliação da resposta vasodilatadora à $\mathrm{ACH}$ em anéis de aorta dos ratos dos diferentes grupos 
Para determinação da função endotelial, anéis de aorta com endotélio précontraídos com FE $0.1 \mu \mathrm{M}$ nos diferentes grupos experimentais foram submetidos à $\mathrm{CCE}$ à $\mathrm{ACH}(0,1 \mathrm{nM}$ a $1 \mu \mathrm{M})$, vasodilatador dependente do endotélio. O relaxamento induzido pela $\mathrm{ACH}$ foi expresso em porcentagem de relaxamento em relação à contração obtida com a FE.

\subsubsection{ESTUDO in vitro DA REATIVIDADE DO LEITO ARTERIOLAR MESENTÉRICO PERFUNDIDO DE RATO}

\subsubsection{Avaliação da resposta vasodilatadora ao DABK, agonista de RB1}

Nesta etapa foi avaliada a resposta ao DABK, agonista de RB1, no leito arteríolar mesentérico perfundido como descrito por McGregor (1965) e modificado por Carvalho et al. (1987). Para isso, ratos dos diferentes grupos experimentais foram anestesiados com hidrato de cloral $(200 \mathrm{mg} / \mathrm{Kg}$, sc), submetidos à laparotomia e o leito mesentérico arteriolar exposto. A artéria mesentérica superior foi canulada com cateter de polietileno (PE-10 Hemo Técnico® - São Paulo, Brasil), introduzido cerca de $1,5 \mathrm{~cm}$ distante da aorta abdominal e o leito mesentérico foi perfundido, com fluxo inicial de $2 \mathrm{~mL} / \mathrm{min}$ com Krebs Henseleit modificado, saturado com 95\% de $\mathrm{O}_{2}$ e $5 \%$ de $\mathrm{CO}_{2}$ e mantido a $37^{\circ} \mathrm{C}$. O mesentério perfundido foi removido do animal, separado da alça intestinal e colocado em cuba de vidro aquecida a $37{ }^{\circ} \mathrm{C}$. Alterações da pressão de perfusão foram detectadas por transdutor de pressão RP1500i, acoplado ao sistema de aquisição de dados (PowerLab/4S, ADInstrument Pty Ltd, Austrália), e utilizadas como medida de contração $(\mathrm{mmHg})$ ou relaxamento $(\mathrm{mmHg})$ vascular induzido pelas drogas utilizadas. Para a CCE ao DABK o fluxo foi ajustado para $4 \mathrm{~mL} / \mathrm{min}$ e após 20 minutos de estabilização o leito arteriolar mesentérico foi perfundido com enalaprilato $10 \mu \mathrm{M}$ por 10 minutos. Após esse período, os vasos foram pré-contraídos com noradrenalina $(\mathrm{NA}-0,1 \mu \mathrm{M})$ em solução de Krebs Henseleit modificado contendo desipramina $(0,01 \mu \mathrm{M})$, inibidor da captura de NA, e, enalapril $(10 \mu \mathrm{M})$ (iECA). Após a estabilização foi realizada injeção "in bolus" (60 $\mu \mathrm{L})$ de DABK nas concentrações de $(0,0001 \mu \mathrm{M}$ a $1000 \mu \mathrm{M})$ a cada 3 minutos. 


\subsubsection{ESTUDO in vivo $e$ in situ DA REATIVIDADE DO LEITO ARTERIOLAR MESENTÉRICO DE RATO}

4.7.3.1 Avaliação da resposta vasodilatadora ao DABK, agonista de RB1 e ao BK, agonista de RB2

Os ratos ANG II foram anestesiados com hidrato de cloral $(200 \mathrm{mg} / \mathrm{Kg}, \mathrm{sc})$ submetidos à laparotomia, o mesentério foi exposto e preparado para observação microscópica de acordo com o método descrito por Zweifach (1948) e modificado por Fortes et al. (1983). Os ratos foram mantidos sobre placa aquecida a $37^{\circ} \mathrm{C}$, que continha um orifício central transparente permitindo a transiluminação do mesentério. Arteríolas de $15-25 \mu \mathrm{m}$ foram utilizadas neste estudo.

Inicialmente uma arteríola foi escolhida, seu diâmetro inicial medido (diâmetro basal) e após este procedimento a arteríola foi superfundida com solução contendo NA $(1 \mu \mathrm{M})$ e desipramina $(0,01 \mu \mathrm{M})$,e $\mathrm{iECA}(10 \mu \mathrm{M})$ até que o fluxo arteriolar fosse interrompido pela contração total do vaso. Posteriormente, foi realizada injeção "in bolus" (100 $\mu \mathrm{L})$ de DABK nas concentrações de $1 \mu \mathrm{M}$ a $1000 \mu \mathrm{M}$, e após cada injeção o diâmetro vascular foi medido durante um período de 3 minutos. Entre cada injeção foi feita lavagem da preparação com Krebs Henseleit contendo desipramina $(0,01 \mu \mathrm{M})$ por um período de 5 minutos. Todas as medidas foram realizadas em um mesmo vaso.

Para controle da capacidade relaxante do vaso, ao término da aplicação de $\mathrm{DABK}$, foi realizado o mesmo procedimento de contração da arteríola com NA $(1 \mu \mathrm{M})$ e posterior injeção "in bolus" de BK $(1 \mu \mathrm{M})$. A medida do diâmetro vascular após a BK foi realizada também durante 3 minutos após aplicação deste peptídeo.

\subsection{ANÁLISE ESTATÍSTICA}

Para a análise estatística dos resultados obtidos na evolução ponderal e pressão arterial foi utilizado o teste One-way ANOVA para dados repetidos, seguido do teste de Bonferroni para comparação entre os grupos. Para as demais análises foram utilizados os testes One-way ANOVA e Kramer-Tukey ou teste T-student quando apropriado 


\section{RESULTADOS}

\subsection{DETERMINAÇÃO DA PRESSÃO ARTERIAL CAUdAL DE RATOS HIPERTENSOS POR INFUSÃO DE ANG II (400ng/Kg/min) POR 28 DIAS}

Os ratos que receberam infusão de ANG \|| apresentaram elevação significativa da pressão arterial a partir da $1^{\circ}$ semana, quando comparados com a pressão arterial do grupo Controle (Figura 4).

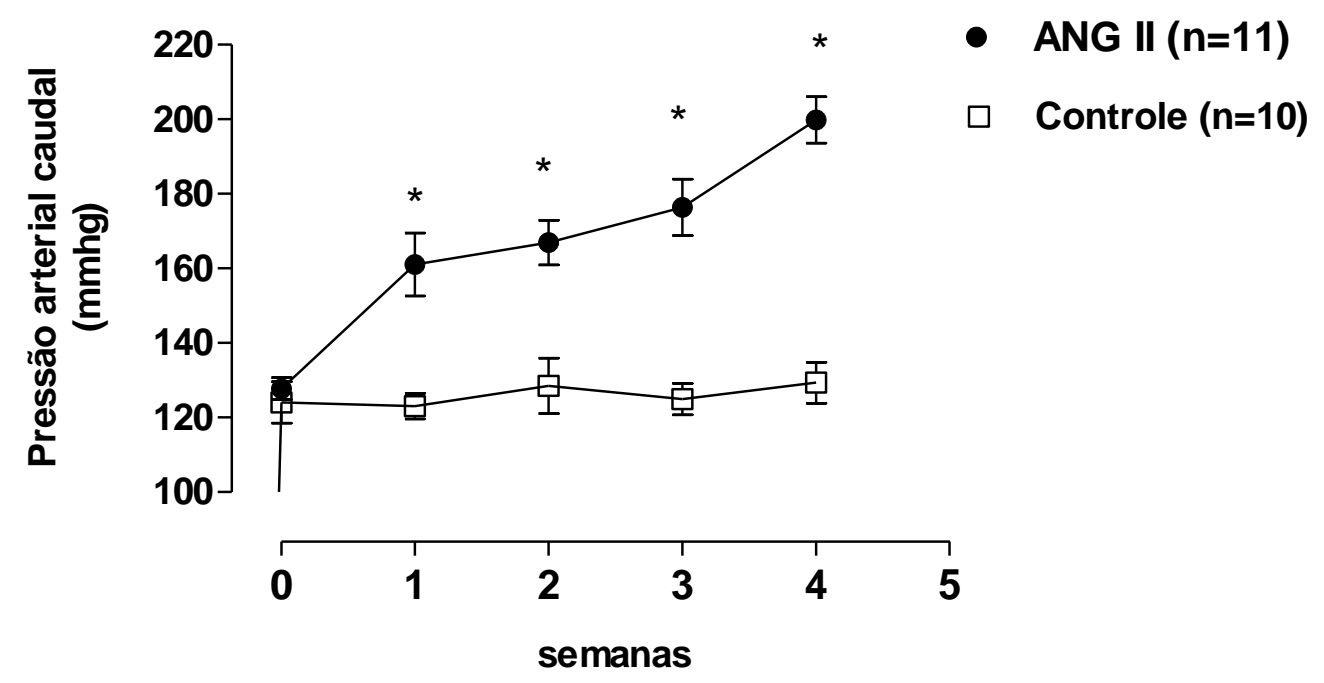

Figura 4. Evolução da pressão arterial caudal $(\mathrm{mmHg})$ de ratos infundidos com ANG II, através de mini-bomba osmótica implantadas no tecido subcutâneo e de ratos Controle nas semanas 1, 2, 3 e 4. Os valores foram expressos como média \pm epm da pressão arterial caudal $(\mathrm{mmHg})$. ${ }^{*} p<0,05$ quando comparados ao Controle em todas as semanas após implante da minibomba de infusão. (n) representa o número de ratos utilizados por grupo. 


\subsection{DETERMINAÇÃO DO RNAm DE RB1 EM AORTA E ARTERÍOLAS MESENTÉRICAS DE RATOS ANG II E CONTROLE POR RT-PCR EM TEMPO REAL}

A aorta e arteríolas mesentéricas (Figura 5) dos ratos ANG II apresentaram maior expressão de RNAm de RB1 de cininas, quando comparados com os mesmos tecidos isolados dos ratos controle.

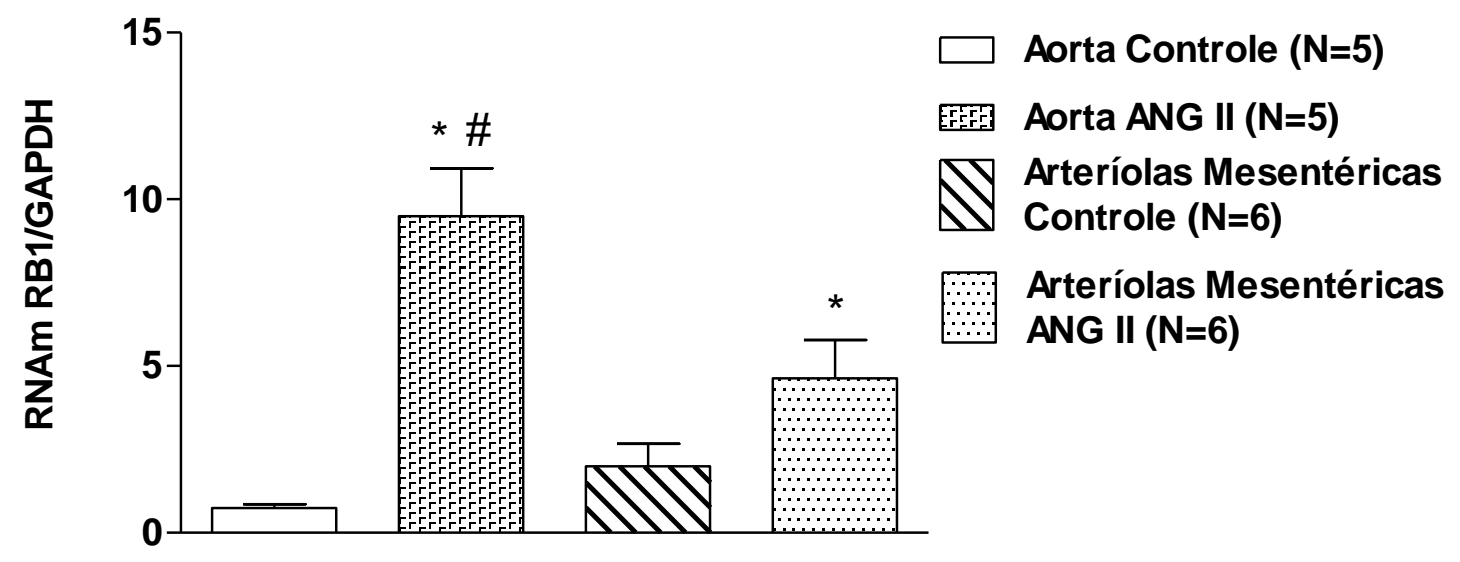

Figura 5. Expressão de RNAm de RB1 de cininas realizada em aorta e arteríolas mesentéricas de ratos do grupo controle e do grupo ANG II avaliadas por RT-PCR tempo real. As barras representam as médias \pm epm da expressão de RNAm de RB1, normalizada pela expressão de RNAm de GAPDH. (n) representa o número de ratos utilizados por grupo. ${ }^{*} p<0,05$ em comparação ao controle, \# $p<0,05$ comparação da expressão de RNAm de RB1 de aorta com aquelas das arteríolas mesentéricas 


\subsection{ESTUDO DE REATIVIDADE VASCULAR in vitro AO DABK, AGONISTA DE}

RB1

\subsubsection{ANÉIS DE AORTA}

A DABK promoveu vasodilatação em anéis de aorta $E_{+}$isolados de ratos ANG II e a remoção do endotélio aboliu o relaxamento causado pelo agonista de RB1 (Figura 6). Em outra série de experimentos os anéis E+ dos ratos ANG II foram incubados com L- NAME, inibidor da óxido nítrico sintase (NOS). Como demonstrado na figura 7, o L-NAME bloqueou a resposta vasodilatadora promovida pela DABK. Estes resultados sugerem que a vasodilatação promovida pela DABK em anéis $E_{+}$ de ratos ANG II depende da presença de endotélio e envolve a geração de NO. A DABK não alterou o tônus vascular nos anéis de aorta $E+$ e E- dos ratos Controle, pré-contraídos com (FE - 0,1 $\mu \mathrm{M})$.

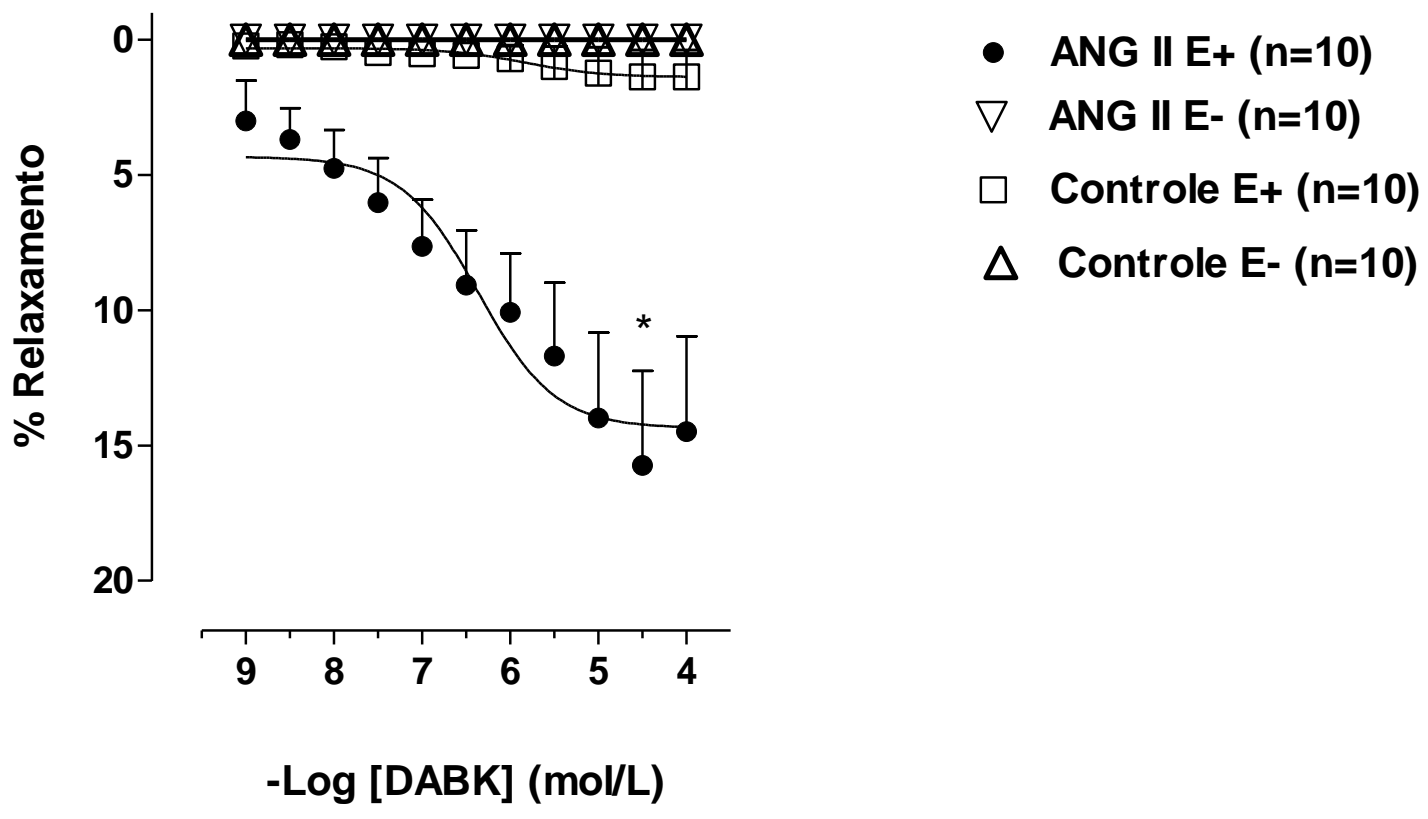

Figura 6. Curvas concentração-efeito à DABK obtidas em anéis de aorta com $E+e$ sem E- endotélio isolados de ratos Controle e ANG II. Os valores foram expressos como médiatepm das porcentagens de relaxamento. * $p<0,001$ comparando a resposta máxima $(\mathrm{Rmax})$ de anéis de aorta $\mathrm{E}+$ do grupo ANG II com aquele do grupo Controle. (n) representa o número de ratos utilizados por grupo. 


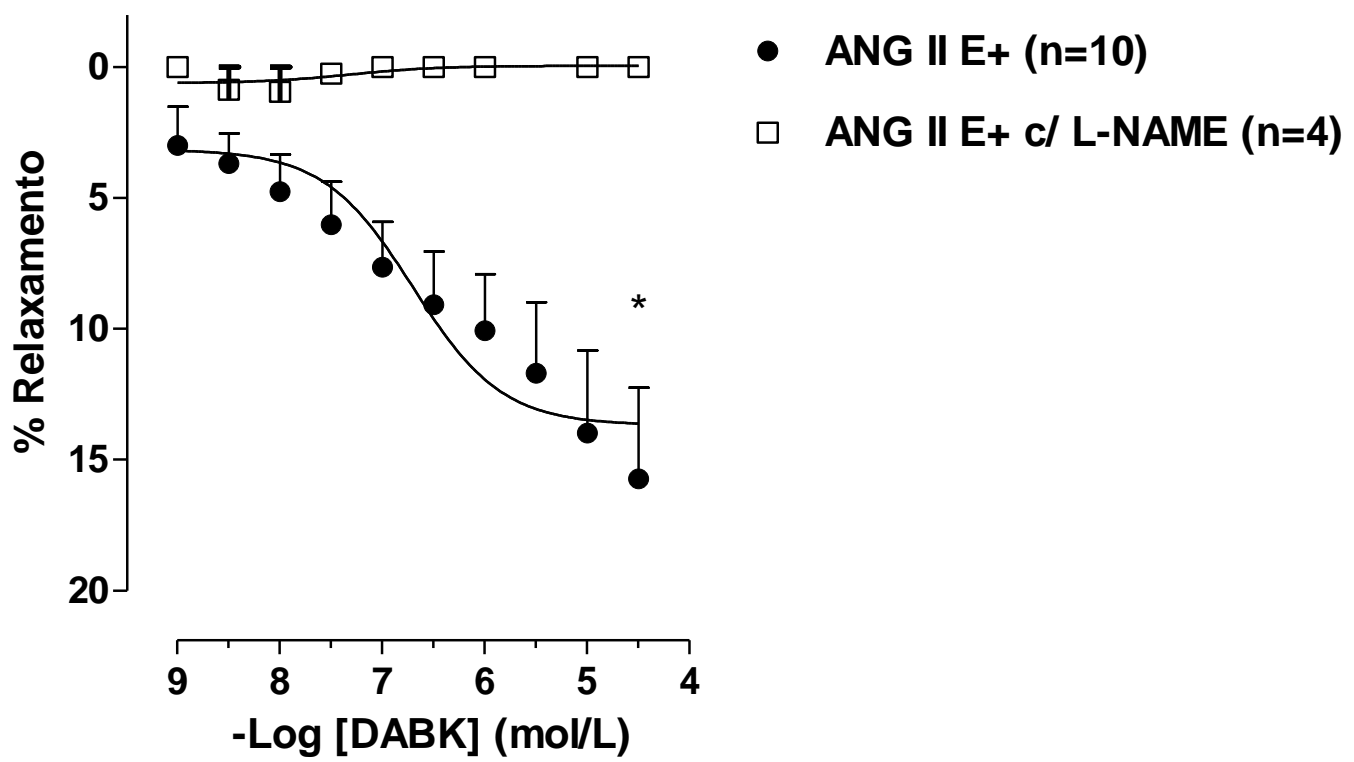

Figura 7. Curvas concentração-efeito à $D A B K$ obtidas em anéis de aorta com $E_{+}$ isolados de ratos ANG II pré-incubadas ou não com L-NAME. Os valores foram expressos como médiatepm das porcentagens de relaxamento. ${ }^{*} p<0,001$ comparando a resposta máxima (Rmax) de anéis de aorta $E_{+}$ do grupo ANG II com aquele do grupo ANG II pré incubado com L-NAME. (n) representa o número de ratos utilizados por grupo. 


\subsubsection{ESTUDO DA REATIVIDADE DE ARTERÍOLAS MESENTÉRICAS}

PERFUNDIDAS in vitro AO DABK, AGONISTA DE RB1

As figuras 8 e 9 representam registros do estudo da resposta à DABK em leito arteriolar mesentérico perfundido. A injeção "in bolus" de DABK não alterou a pressão de perfusão neste leito vascular de ratos ANG II $(n=4)$ e Controle $(n=4)$.

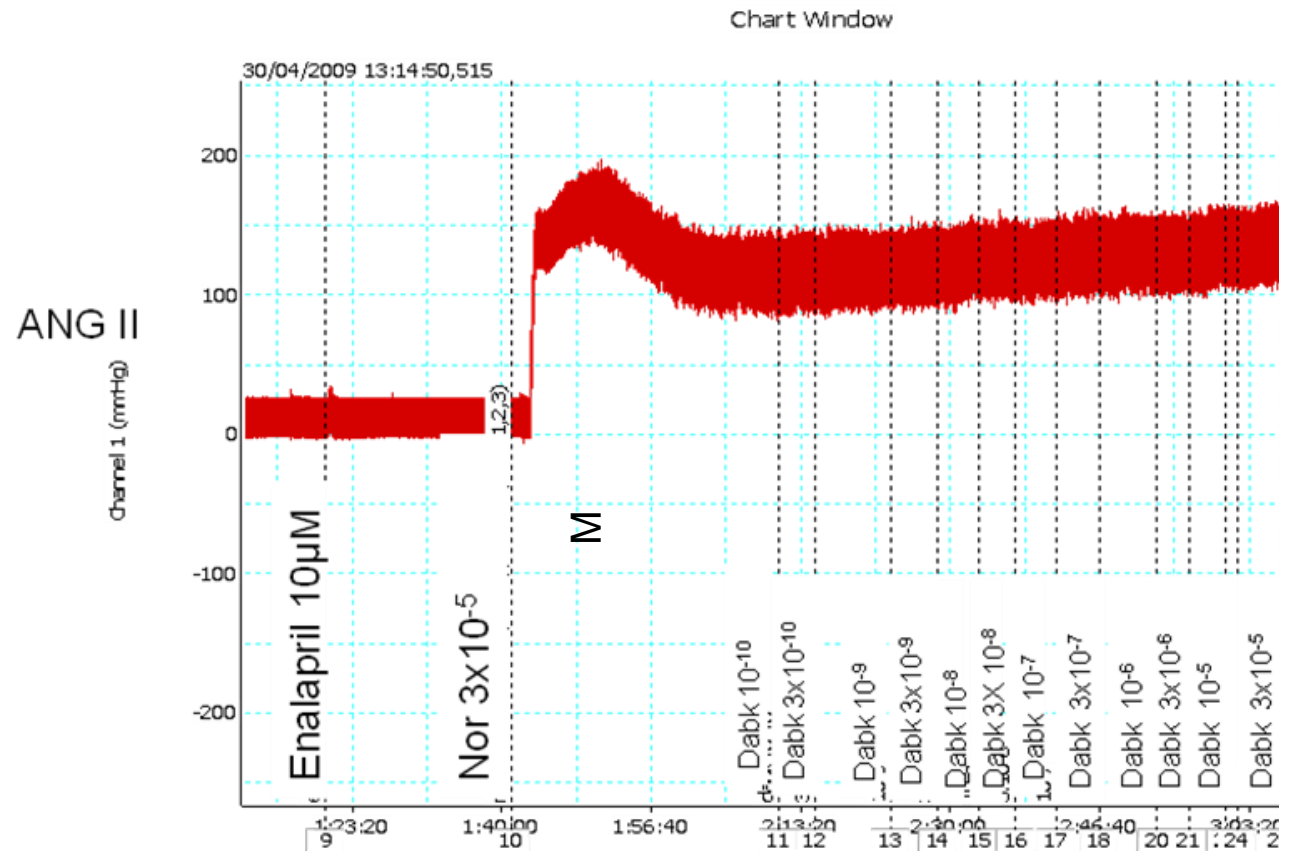

Figura 8. Registro típico obtido com a perfusão do leito arteriolar mesentérico de ratos ANG II com NA e com injeção "in bolus" de diferentes concentrações molares de DABK 


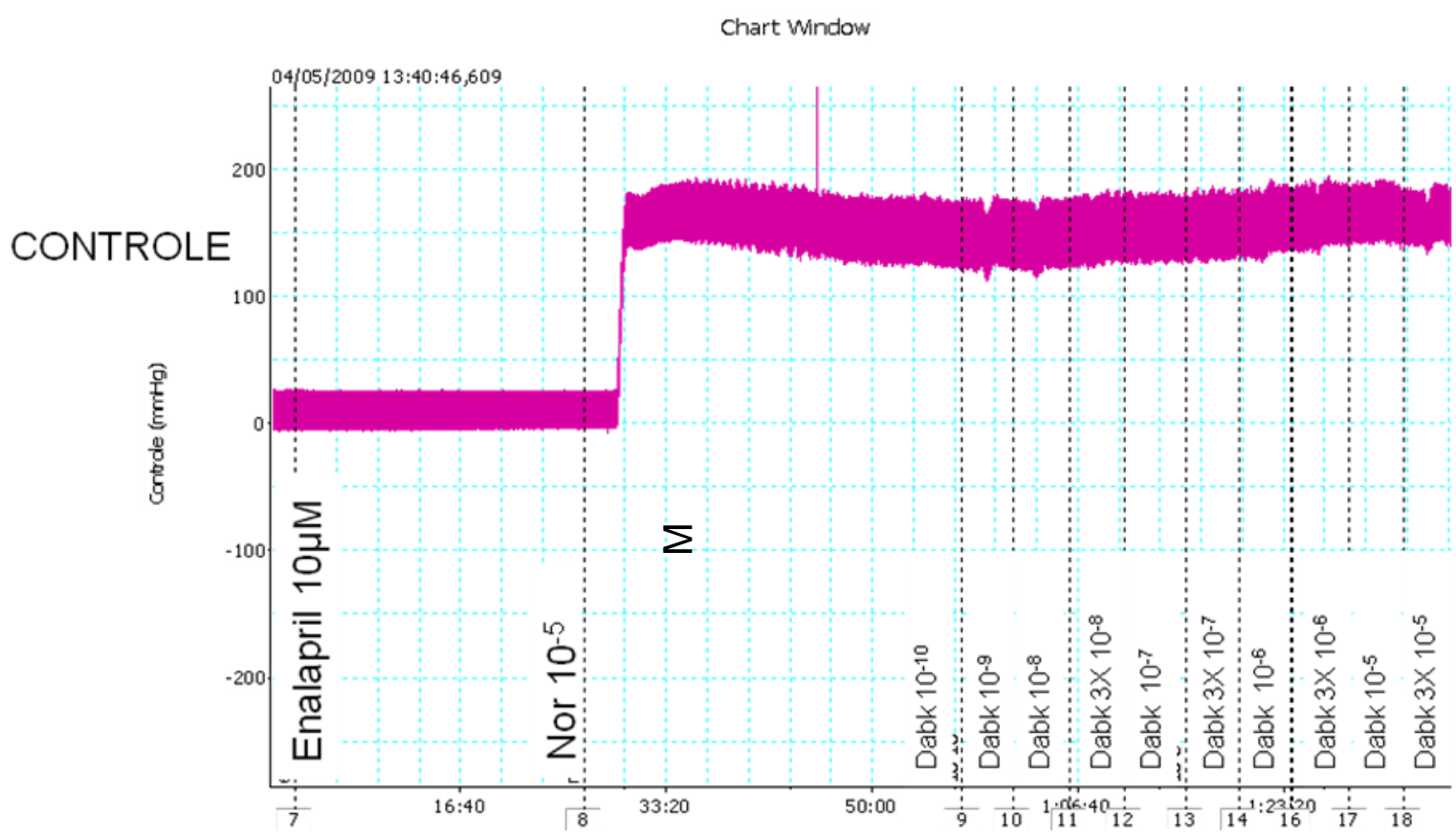

Figura 9. Registro típico obtido com a perfusão do leito arteriolar mesentérico de ratos Controle com NA e com injeção "in bolus" de diferentes concentrações molares de DABK 


\subsubsection{ESTUDO in vivo DA REATIVIDADE DE ARTERÍOLAS MESENTÉRICAS AO}

DABK, AGONISTA DE RB1 E BK, AGONISTA RB2

A NA $(1 \mu \mathrm{M})$ causou $100 \%$ de contração, parada de fluxo, nas arteríolas mesentéricas dos ratos ANG II. A injeção "in bolus" com DABK não alterou a reatividade deste leito vascular de ratos ANG II, da BK, agonista RB2 de cinina, causou $100 \%$ de vasodilatação. Esses dados nos sugerem que as concentrações utilizadas do agonista de RB1 de cininas não altera a reatividade vascular do leito arteriolar mesentérico estudado "in vivo". (figuras 10 A, B, C, D, E, F)

A

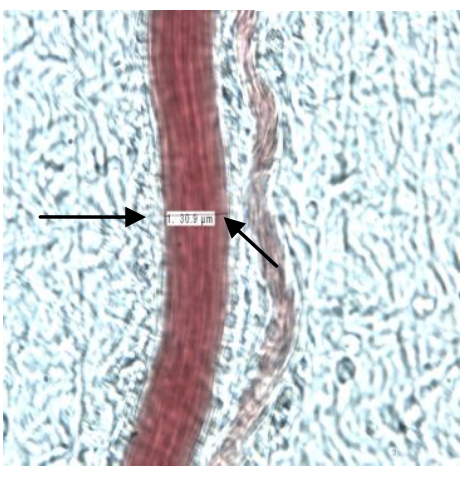

Diâmetro Basal

D

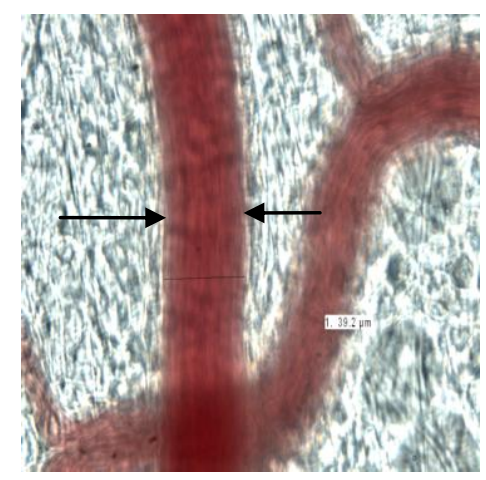

Diâmetro Basal
B

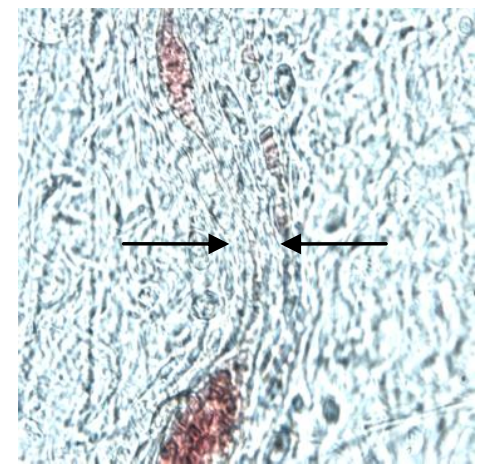

Noradrenalina $10^{-6} \mathrm{M}$

$E$

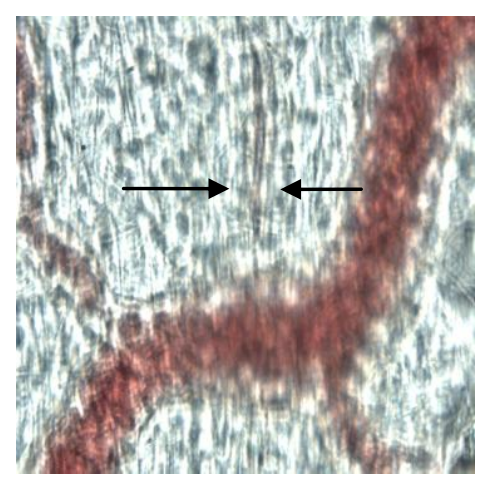

Noradrenalina $10^{-6} \mathrm{M}$
C

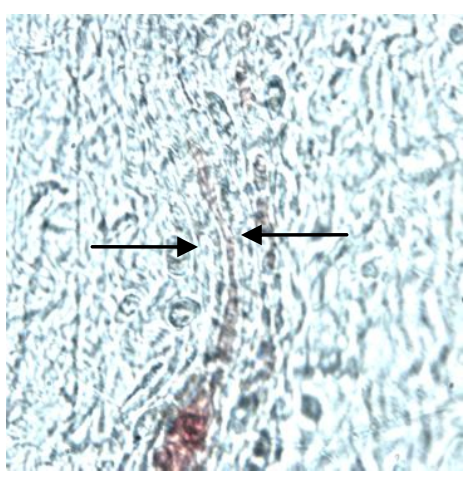

DABK $10^{-6} \mathrm{a} 10^{-3} \mathrm{M}$

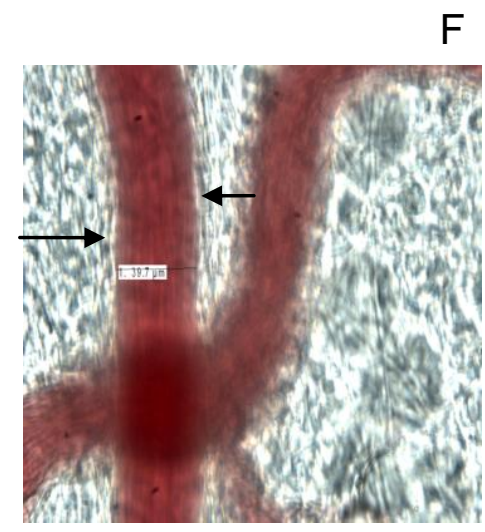

Bradicinina $10^{-6} \mathrm{M}$

Figuras 10. Imagens típicas obtidas no estudo in vivo e in situ de reatividade de arteríolas mesentéricas de ratos ANG II. A) Imagem da medida do diâmetro basal; B) Imagem da pré-contração com NA (1 $\mu \mathrm{M}) \quad 100 \%$ de contração; C) Imagem representativa da aplicação "in bolus" de DABK (1 mM); D) Imagem da medida do diâmetro basal; E)lmagem da précontração com NA $(1 \mu \mathrm{M}), 100 \%$ de contração; F) Imagem representativa aplicação "in bolus"de BK $(1 \mu \mathrm{M})$ 


\subsection{DETECÇÃO E LOCALIZAÇÃO DA EXPRESSÃO PROTÉICA DO RB1 EM AORTA E ARTERÍOLAS MESENTÉRICAS DE RATO POR IMUNOHISTOQUÍMICA}

As aortas de ratos ANG II apresentaram expressão protéica de RB1 no endotélio e adventícia já, nos ratos Controles, o RB1 somente se expressou na adventícia. O grupo controle negativo não apresentou expressão protéica do RB1 em nenhuma região. (Figuras $11 \mathrm{~A}, \mathrm{~B}, \mathrm{C}$ )

As arteríolas mesentéricas de ratos ANG II, Controle e o grupo Controle negativo não apresentaram expressão protéica RB1 em nenhuma região. (Figuras $10 \mathrm{D}, \mathrm{E}, \mathrm{F})$
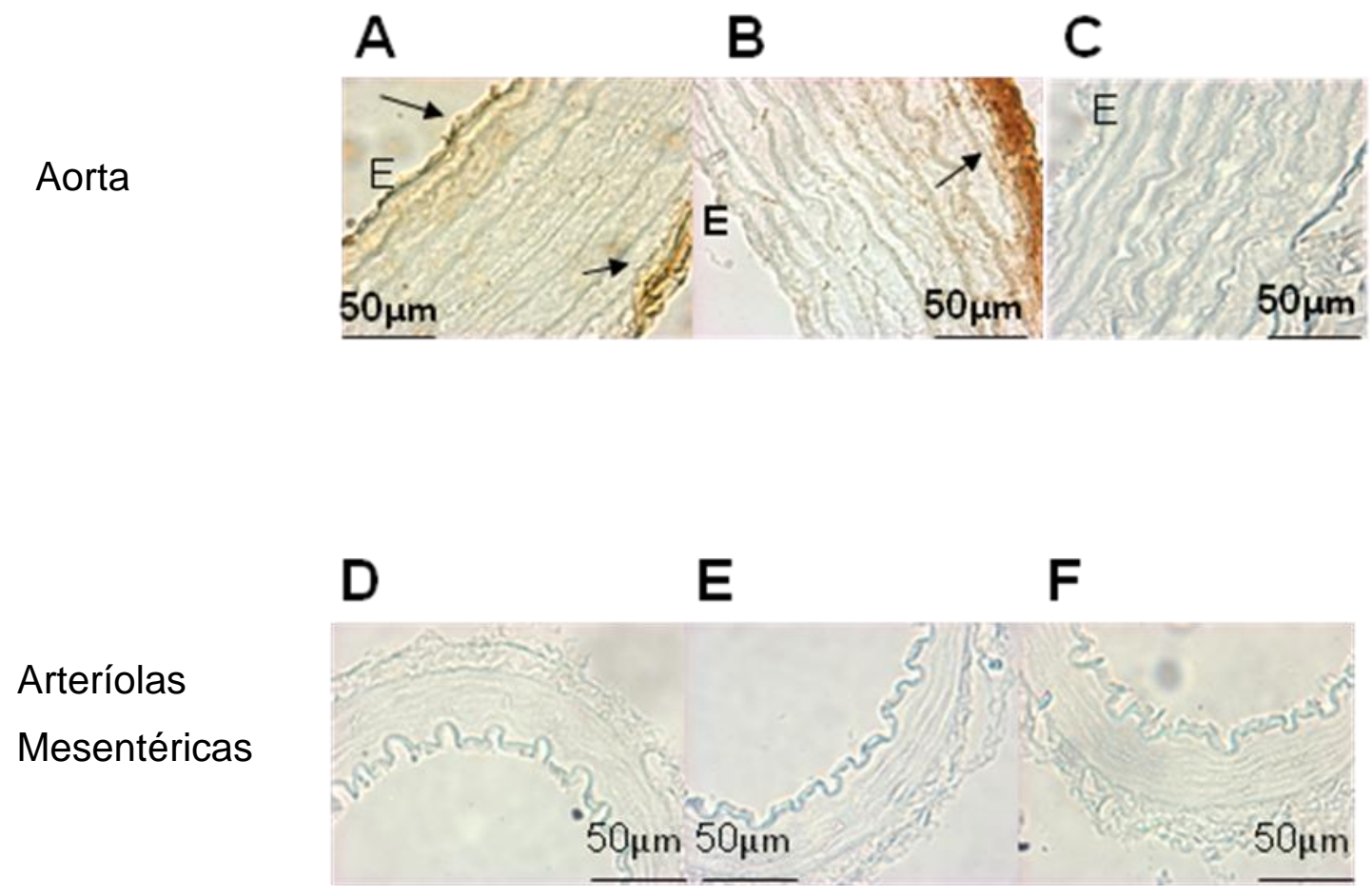

Figura 11. Expressão protéica e localização do RB1 em aorta e ateríolas mesentéricas de ratos: Imagens representativas da imunuhistoquímica para o anticorpo anti-receptor B1 A) em cortes de aorta de ratos ANG II (400 $\mathrm{ng} / \mathrm{Kg} / \mathrm{min}$ ), B) em cortes de aorta de ratos controle, C) em cortes de aorta de ratos (controle negativo), D) em cortes de arteríolas mesentéricas de ratos ANG II (400ng/Kg/min), E) em cortes arteríolas mesentéricas de ratos controle, $\mathrm{F}$ ) em cortes de arteríolas mesentéricas de ratos (controle negativo). Em todas as figuras $\mathrm{E}$ indica a camada endotelial e as setas indicam a localização de RB1 de cininas. 


\subsection{DETERMINAÇÃo DA PREssão ARTERIAL CAUdAL DE RATOS INFUNDIDOS COM ANG II (400ng/Kg/min), COM E SEM TRATAMENTO COM des-arg9-leu8-bradicinina (DAL) POR 28 DIAS}

Os ratos que receberam infusão de ANG \| e ANG \| + DAL apresentaram elevação significativa da pressão arterial caudal a partir da $1^{\circ}$ semana, quando comparados com a pressão arterial caudal do grupo Controle (Figura 12).

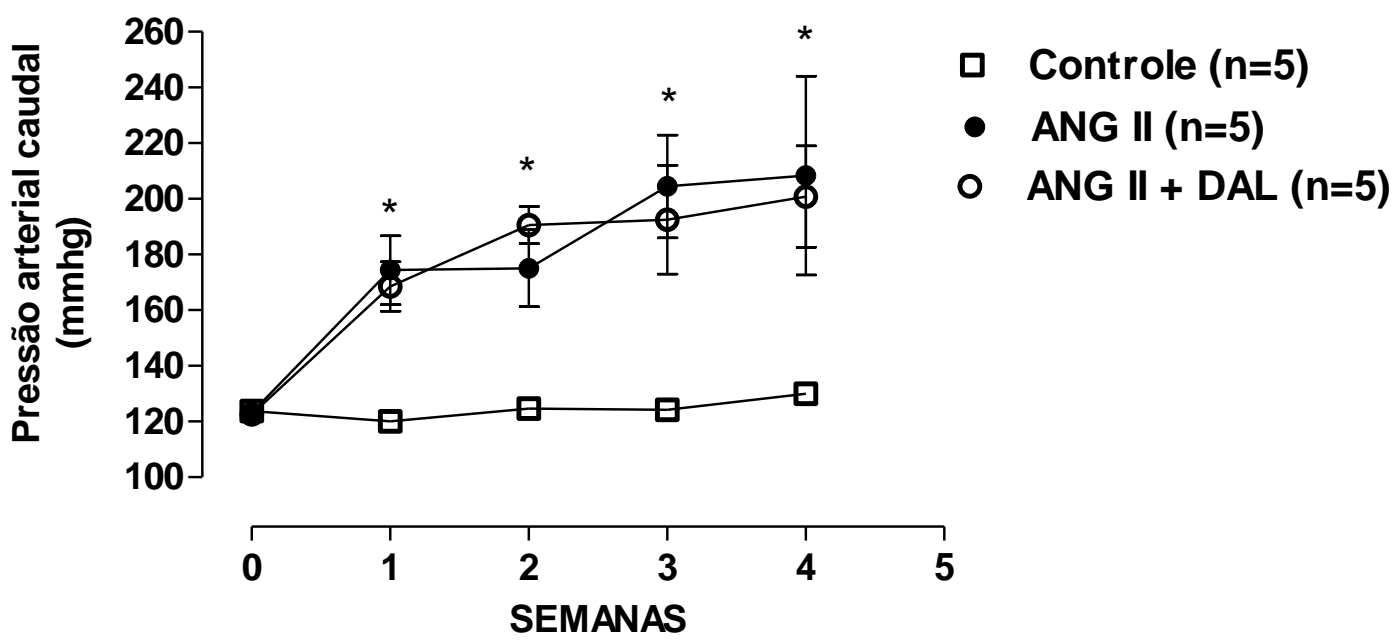

Figura 12. Evolução temporal da pressão arterial caudal $(\mathrm{mmHg})$ de ratos infundidos com ANG II, ANGII + DAL através de mini-bomba osmótica implantadas no tecido subcutâneo e de ratos Controle nas semanas $1,2,3$ e 4 . Os valores foram expressos como média \pm epm da pressão arterial caudal ( $\mathrm{mmHg}$ ). ${ }^{*} p<0,05$ quando comparados ao Controle em todas as semanas após implante da mini-bomba de infusão. (n) representa o número de ratos utilizados por grupo. 


\subsection{REATIVIDADE DE ANÉIS DE AORTA COM ENDOTÉLIO PARA ACH APÓS ANTAGONISMO DO RECEPTOR B1 DAL EM RATOS ANG II}

Observamos que a resposta máxima à $\mathrm{ACH}$, vasodilatador dependente de endotélio, foi menor nos anéis de aorta dos ratos ANG II e ANG II + DAL quando comparada àquela dos ratos controle. Isso nos sugere que há disfunção endotelial nos anéis de aorta dos ratos ANG II e ANG II + DAL quando comparados com aquele do grupo Controle. Verificamos também que anéis de aorta de ratos ANG II + DAL apresentaram aumento na sensibilidade (pD2) à acetilcolina quando comparados àqueles dos ratos ANG II. (Figuras 13,14 e 15) .

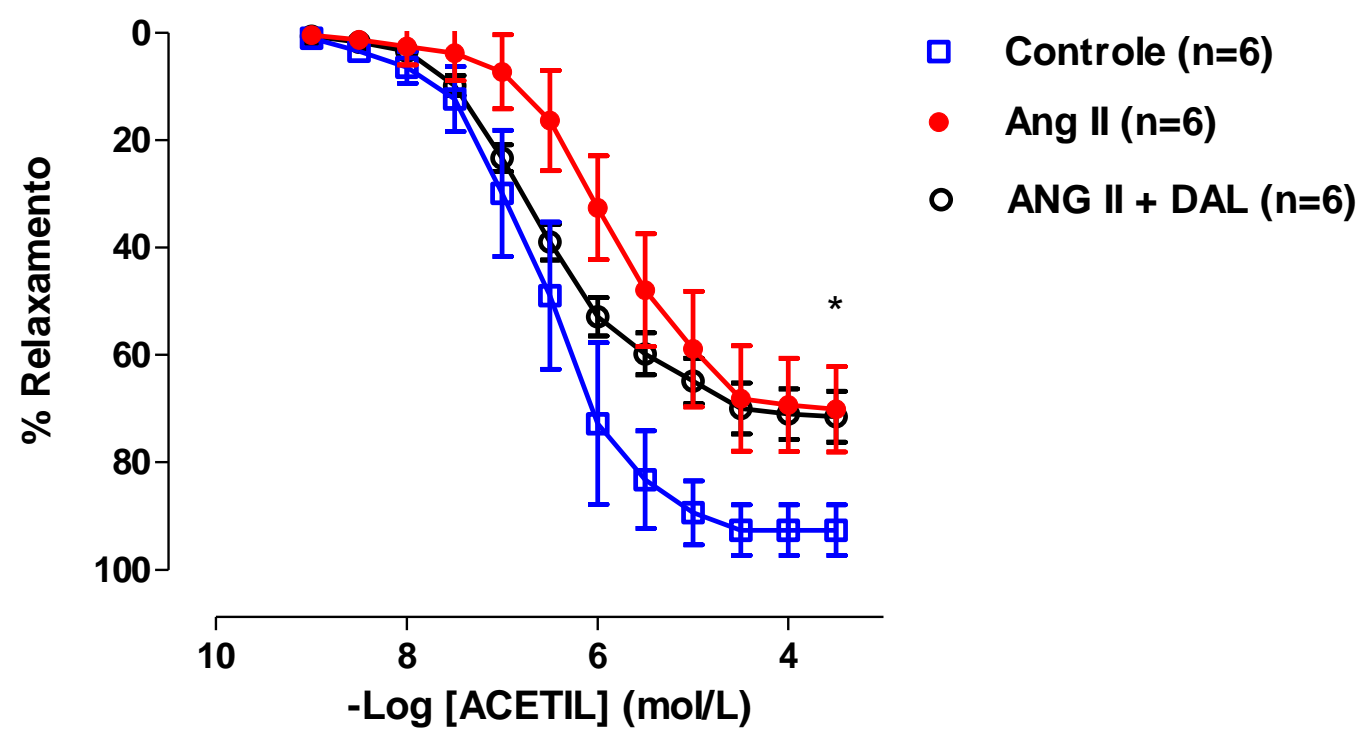

Figura 13. Curva concentração-efeito à $\mathrm{ACH}$ obtidas em anéis de aorta com endotélio isolados de ratos ANG II, ANG II + DAL e Controle. Os valores foram expressos como médiatepm das porcentagens de relaxamento. (n) representa o número de ratos utilizados por grupo. * $\mathrm{p}<0,05$ comparado com Controle. 


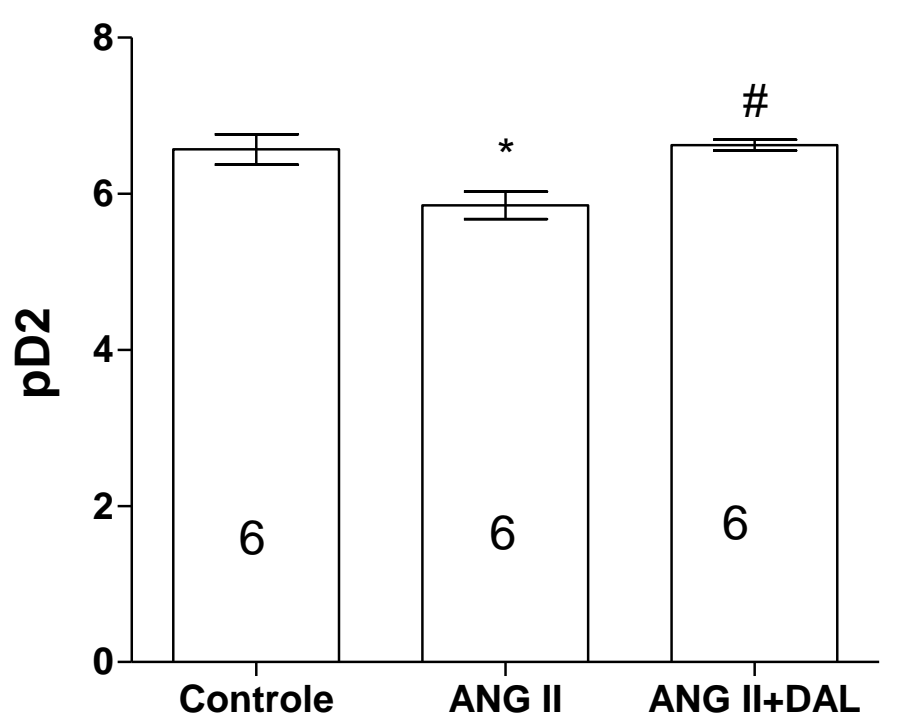

Figura 14. Valores de pD2 para $A C H$ em anéis de aorta com endotélio isolados de ratos ANG II, ANG II + DAL e Controle. Os valores foram expressos como médiatepm das porcentagens de relaxamento. $O$ número de ratos utilizados em cada grupo encontra-se dentro das barras. ${ }^{*} p<0,05$ comparado com Controle, ${ }^{\#} p<0,05$ comparados com ANG II.

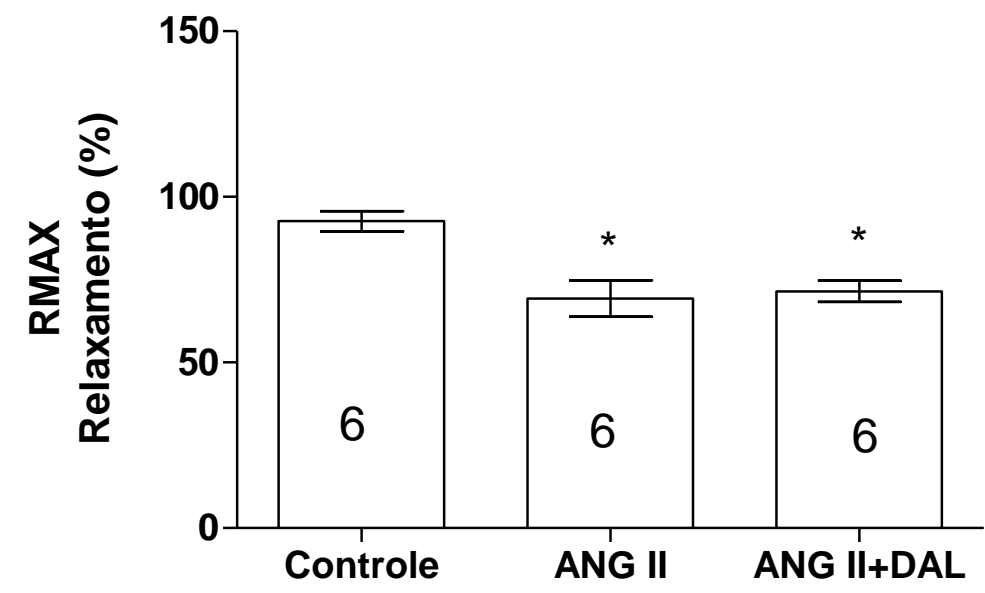

Figura 15. Valores da resposta máxima para $A C H$ em anéis de aorta com endotélio isolados de ratos ANG II, ANG II + DAL e Controle, pré-contraídos com fenilefrina 10-6M. Os valores foram expressos como médiatepm das porcentagens de relaxamento. O número de ratos utilizados em cada grupo encontra-se dentro das barras. ${ }^{*} \mathrm{p}<0,05$ comparado com Controle. 


\subsection{DETERMINAÇÃO DO RNAm POR RT-PCR EM TEMPO REAL DA ENOS EM AORTA DE RATOS}

\subsubsection{EXPRESSÃO DE RNAm DE eNOS EM AORTA}

A expressão de RNAm da eNOS em aorta dos ratos ANG II foi menor quando comparada àquela do grupo controle. O tratamento com DAL, antagonista de RB1, restaurou a expressão da eNOS para nível daquele encontrado nas aortas de ratos controle (Figura 16).

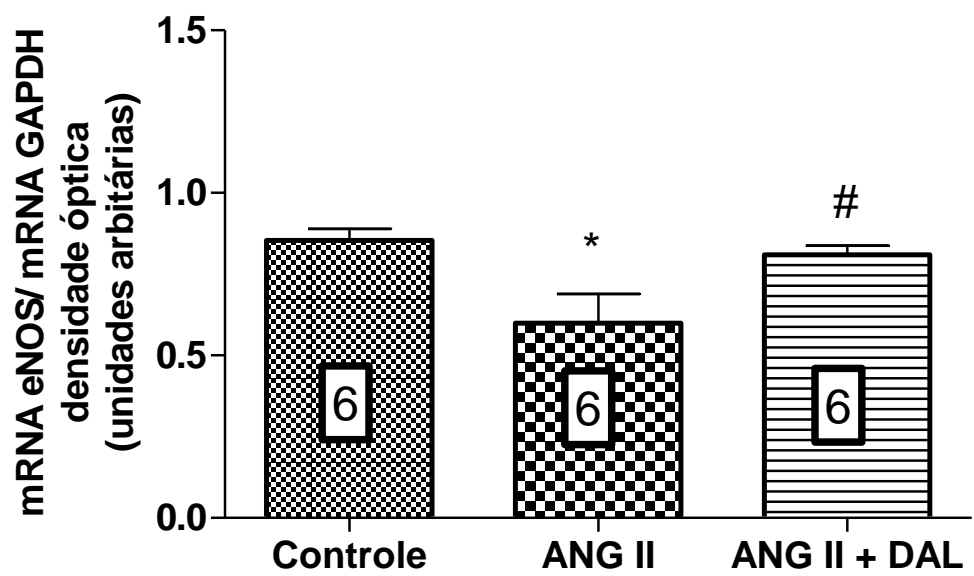

Figura 16. Expressão de RNAm de eNOS verificada em aorta de ratos ANG II, ANG II+ DAL e Controles avaliadas por RT-PCR em tempo real. As barras representam as médias \pm epm da expressão de RNAm da eNOS, normalizada pela expressão de RNAm de GAPDH O número de ratos utilizados em cada grupo encontra-se dentro das barras. ${ }^{*} p<0,05$ comparado com Controle, ${ }^{\#} p<0,05$ comparados com ANG II. 


\section{DISCUSSÃO}

Neste trabalho demonstramos que a infusão de ANG II por 28 dias, em ratos Wistar, modula a expressão de RNAm de RB1 de cininas em macro e microvasos e que este receptor parece estar envolvido na disfunção endotelial observada na aorta de ratos hipertensos por infusão de ANG II.

Além desses efeitos, demonstramos que a infusão de ANG \|l causou elevação dos níveis pressóricos de ratos Wistar. Vários estudos demonstram a participação da ANG I| na gênese e manutenção da hipertensão arterial em diferentes modelos experimentais, como por exemplo, modelo G2 (dois rins um clipe) desenvolvido por Goldblatt em 1934. Neste estudo o autor demonstrou que o clampeamento da artéria renal, causava redução da perfusão renal com consequente aumento de renina , ANG II plasmática e elevação da pressão arterial.

A ANG II causa elevação da pressão arterial por atuar em diferentes sistemas biológicos. Por exemplo, este peptídeo atuando em receptor AT1 no músculo liso vascular causa vasoconstrição e conseqüente aumento da resistência vascular periférica, no córtex da adrenal aumenta secreção de aldosterona, que por sua vez, atua em receptores para mineralocorticóides no túbulo distal incrementando a retenção de sódio e reabsorção de água (WEIR et al., 1999). A ANG II também promove aumento da atividade simpática, por reduzir recaptação de noradrenalina (NA) nas terminações simpáticas, causando vasoconstrição, aumento do débito cardíaco e também induz a liberação de renina (SCHIFFRIN et al., 2002; SILVERSTEIN et al., 2004)

Vários estudos também sugerem a importante participação do SCC, na homeostase do SCV e conseqüentemente no controle da pressão arterial (DUKA et al., 2001). As cininas exercem seus efeitos biológicos pela ativação de seus receptores, RB1 e RB2, que diferem entre si em diversos aspectos, dentre eles suas expressões. O RB2 é expresso constitutivamente na maioria das células enquanto 0 RB1 é pouco expresso ou ausente em situações fisiológicas (BHOOLA et al., 1992; FERNANDES et al., 2006).

Neste trabalho observamos pela primeira vez que a infusão de ANG II por 28 dias causa aumento da expressão de RNAm de RB1 em arteríolas mesentéricas envolvidas com o controle da pressão arterial e também na aorta. A expressão de 
RNAm de RB1 foi comparada entre esses leitos vasculares, observamos que a aorta apresentou maior expressão de RNAm em relação a expressão nas arteríolas, sugerindo que esta modulação causada pela ANG II pode acontecer de forma tecido dependente.

O efeito modulador da ANG II sobre a expressão de RB1, descrito no presente trabalho, está de acordo com o descrito por kintsurashvili et al., que, em, demonstraram que a infusão de ANG II causa aumento de RNAm RB1 e RB2 em cultura de células de músculo lisa de aorta torácica de ratos. Este efeito modulador da ANG II sobre a expressão de RB1 foi reproduzido in vivo em nosso laboratório, onde demonstramos que diferentes modelos de hipertensão dependentes de ANG II apresentam aumento da expressão de RB1 no sistema cardiovascular (FERNANDES et al., 2006; CERAVOLO et al., 2007)

Diversos mecanismos vêem sendo propostos para explicar o efeito modulador da ANG II sobre a expressão de RB1. Foi demonstrado que esta modulação é dependente de receptor AT1 de ANG II (KINTSURASHVIL et al., 2001; FERNANDES et al., 2006), da geração de espécies reativas de oxigênio (EROs) e da ativação do NF-kB (CERAVOLO et al., 2007). Além disso, a ANG II em cultura de células de músculo liso de aorta de ratos, induz indiretamente a expressão de RB1 por liberar endotelina a qual via receptor ET $A$ ativa a via $\mathrm{PI} 3 \mathrm{~K}$, induz a geração de EROs e NFKB (MARIELLE MORAND-CONTANT et al., 2010).

Os primeiros trabalhos que descreveram a presença funcional de RB1 foram realizados em estudos farmacologicos com orgaos isolados. Foi demonstrado que íleo de cobaia respondem à des-Arg-bradicinina,agonista de RB1, somente após a incubaçao dessa preparação com solucao fisiológica por quatro horas ,sugerindo assim a síntese protéica desse receptor caracterizando sua natureza induzivel. De fato, no presente trabalho observamos que além do aumento da expressao de RNAm, a infusao de ANG II causou aumento da expressao protéica do RB1 na aorta. Por outro lado, em arteríolas mesentéricas apesar do aumento da expressão do RNAm para RB1 não foi possível detectar expressão protéica nestes vasos. A não detecção da expressão protéica de RB1 poderia estar relacionada a vários fatores tais como: baixa sensibilidade da técnica de imunohistoquímica, a não tradução do RNAm em proteína, a rápida ação de proteases sobre a proteína recém sintetizada como também é verificado em outros tecidos e receptores 
Para caracterizarmos o papel funcional do RB1 expresso no tecido vascular, avaliamos a reatividade da aorta e de arteríolas mesentéricas ao DABK, agonista de RB1, nos diferentes grupos experimentais.

Em anéis de aorta de ratos ANG II, o agonista de RB1 causou vasodilatação dependente de endotélio e da geração de NO. Estes resultados estão em concordância com os observados em modelos de inflamação onde a DABK causa vasodilatação dependente do endotélio na circulação coronária de rato (MCLEAN et al., 1999), boi (DRUMMOND, 1995) e porco (PRUNEAU et al., 1996), em arteríolas mesentéricas e artéria carótida de coelho (PRUNEAU et al.,1993).

Apesar da vasodilataçao promovida pelo DABK na aorta, este agonista de RB1 não promoveu alteração na reatividade de arteríolas mesentéricas tanto in vivo quanto in vitro. Esta ausência de efeito pode estar relacionada com a baixa expressão protéica de RB1 encontrada nas arteríolas mesentéricas dos ratos ANG II. Esse resultado poderia até justificar a não observância de efeitos do antagonista de RB1 no desenvolvimento da hipertensão por infusão de angiotensina II observado nesse trabalho.

Esses resultados estão de acordo com os demonstrados em camundongos por Emanueli et al. (1999) e Pesquero et al. (2000), onde a deleção gênica de receptores $B 1$ não alterou os níveis pressóricos.

Entretanto alguns outros estudos sugerem que este receptor de cininas participe no controle central da pressão arterial de ratos SHR (ALVAREZ et al., 1992) e que sua expressão no hipocampo seria responsável pela manutenção dos níveis pressóricos elevados nesses animais (QUADRI et al., 2002). Em nosso laboratório Fernandes et al. (2006) demonstrou que em SHR o RB1 não era expresso perifericamente em tecidos envolvidos com controle da pressao arterial, como rim e microcirculação mesentérica, sugerindo que perifericamente o RB1 parece não estar envolvido no controle da pressão arterial (trabalho não publicado).

É importante ressaltar que a participação efetiva do RB1 na pressão arterial ainda é assunto controverso. Foi demonstrado que em camundongo knockout para receptores $\mathrm{B} 2$, onde houve aumento da expressão de receptores B1 no sistema cardiovascular que sua ativação elevaria os níveis pressóricos (DUKA et al., 2001). Além disso, quando os RB1 são induzidos por estímulos inflamatórios, como LPS, e ativados por seu agonista, os receptores B1 causam hipotensão em coelho (REGOLI et al., 1981), porco (SIEBECK et al., 1989) e cachorro (NAKHOSTINE et al., 1993). 
Injuria vascular e disfunção endotelial são considerados eventos críticos para o desenvolvimento de doenças cardiovasculares.

Verificamos em nossos estudos que as aortas dos ratos que receberam infusão de ANG II e ANG II + DAL apresentaram redução da resposta à acetilcolina, agente vasodilatador dependente de endotélio demonstrando, portanto, disfunção endotelial nesse vaso.

A alteração da produção de $\mathrm{NO}$, bem como a diminuição de sua biodisponibilidade, o que interfere diretamente na função endotelial, pode ocorrer por vários mecanismos tais como deficiência do substrato L-arginina, aumento de espécies reativas de oxigênio (EROs) como por exemplo o ânion superóxido e redução da atividade/expressão da eNOS (LI, 2004).

De fato observamos que a ANG II promoveu redução na expressão de RNAm da enzima eNOS, o que pode interferir na produção de NO no endotélio da aorta e conseqüentemente reduzir a vasodilatacao promovida pela acetilcolina. Além disso, o antagonismo de RB1 restaurou a expressão do RNAm da eNOS em aorta de ratos ANG II e também aumentou a sensibilidade à acetilcolina, sugerindo que RB1 pode modular a expressão de enzimas envolvidas com a produção de NO.

Em resumo demonstramos que:

* A infusão de ANG II induziu hipertensão arterial em ratos Wistar

* A infusão de ANG II induziu a expressão de RNAm de RB1 de cininas em aorta e arteríolas mesentéricas, porém a expressão protéica desse mesmo receptor foi detectada somente em aortas.

- Em anéis de aorta isolada de ratos de ratos ANG II, o agonista de RB1 causou vasodilatação dependente de endotélio e da geração de NO, porém esse agonista não promoveu alteração na reatividade de arteríolas mesentéricas tanto in vivo quanto in vitro.

* Não houve diferença no desenvolvimento da hipertensão arterial de ratos do grupo ANG II + DAL quando comparado com ratos do grupo ANG II.

* Em anéis de aorta isolados de ratos ANG II e ANG II + DAL a RMAX à $\mathrm{ACH}$ foi menor quando comparados com aqueles dos ratos Controle, porém a pD2 foi maior no grupo ANG II + DAL.

* Em anéis de aorta isolados de ratos do grupo ANG II + DAL a expressão de RNAm da eNOS foi maior que a encontrada em ratos do 
grupo ANG II e também foi restaurada para nível similar daquele encontrado nos ratos do grupo Controle. 


\section{CONCLUSÕES}

Nossos resultados nos permitem sugerir que a ANG II modula a expressão de RNAm de RB1 na aorta de ratos e que este receptor de cininas pode contribuir de maneira sinérgica para alguns dos efeitos vasculares da ANG II, tal como disfunção endotelial, entretanto não estaria participando no desenvolvimento da hipertensao arterial.

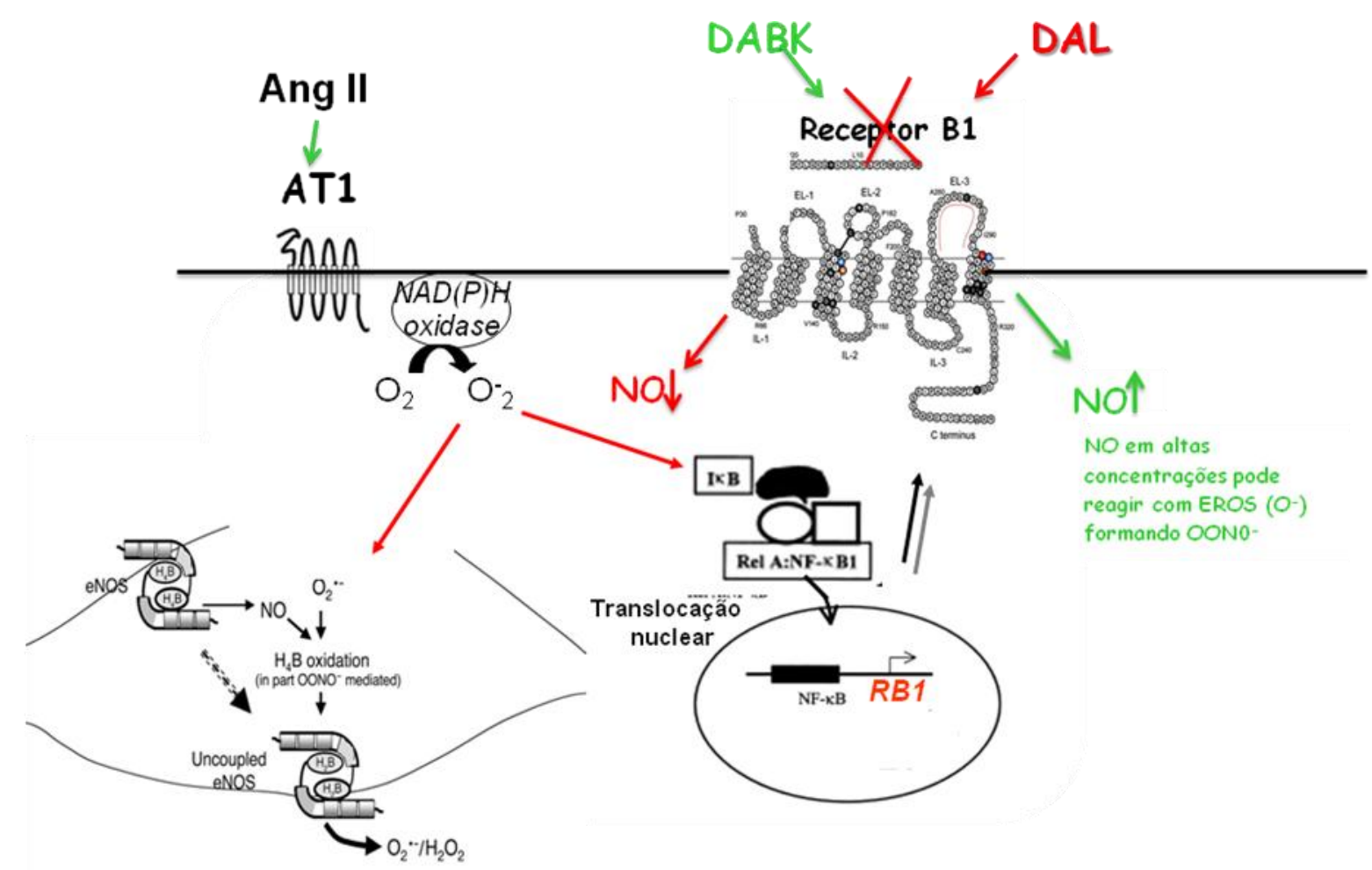

Figura 17. Esquema representativo da interação de ANG II e receptor B1 de cininas: provável mecanismo de ação. (ANG II) angiotensina II, (AT1) receptor de andiotensina II, (NAD(P)H oxidase) nicotine adenine dinucleotide phosphate na forma reduzida, (DABK) agonista RB1, (DAL) antagonista RB1, (NO) óxido nítrico, (NF-kB) fator de transcrição nuclear,(eNOS) óxido nítrico sintase endotelial, $\left(\mathrm{O}^{-2}\right)$ ânion superóxido,(OONO) peróxinitrito, $\left(\mathrm{H}_{2} \mathrm{O}_{2}\right)$ peróxido de hidrogênio, $\left(\mathrm{H}_{4} \mathrm{~B}\right)$ cofator tetrahidrobiopterin 


\section{REFERÊNCIAS*}

ABDÜL, P.; FELIX, D.; KHOSLA, M. C. [D-Ala7-Ang-(1-7)]: Selective antagonism of angiotensin-(1-7) in the rat paraventricular nucleus. Brain Res. Bull., v. 35, n. 4, p. 289-291, 1994.

ALVAREZ, A. L.; DELORENZI A.; SANTAJULIANA, D. et al. Central kininergic system in normotensive and hypertensive rats. Clin. Sci. (Colch), v. 82, n. 5, p. 513519, 1992.

BHOOLA, K. D.; FIGUEROA, C. D.; WORTHY, K. Bioregulation of kinins: kallikreins, kininogens and kininases. Pharmacol. Rev., v. 44, n. 1, p. 1-80, 1992.

BLAIS Jr., C.; DRAPEAU, G.; RAYMOND, P.; LAMONTAGNE, D.; GERVAIS N.; VENNEMAN, I.; ADAM, A. Contribution of angiotensin-converting enzyme to the cardiac metabolism of bradykinin: an interspecies study. Am. J. Physiol., v. 273, p H2263-H2271, 1997.

BUSSE, R.; FLEMING, I. Molecular responses of endothelial tissue to kinins. Diabetes, v. 45, n. S1, p. S8-S13, 1996.

CERAVOLO, G. S.; FERNANDES, L.; MUNHOZ, C. D.; FERNANDES, D. C.; TOSTES, R. C.; LAURINDO, F. R.; SCAVONE, C.; FORTES, Z. B.; CARVALHO, M. $\mathrm{H}$. Angiotensin II chronic infusion induces $\mathrm{B} 1$ receptor expression in aorta of rats. Hypertension, v. 50, n. 4, p. 756-761, 2007.

CERAVOLO, G. S.; FERNANDES, L.; TOSTES, R. C. P.; FORTES, Z. B.; CARVALHO, M. H. C. B1 receptor antagonism reduced the wall thickness of aorta in angiotensin II infused rats. Hipertensão, v. 10, p. 183, 2007. Suplemento. Apresentado no Congresso da Sociedade Brasileira de Hipertensão, 2007.

CONTANT, M. M.; ANAND-SRIVASTAVA, M. B.; COUTURE, RÉJEAN. Kinin B1 receptor upregulation by angiotensin II and endothelin-1 in rat vascular smooth muscle cells: receptors and mechanisms Am. J. Physiol. Heart Circ. Physiol., v. 299, p. H1625-H1632, 2010.

* De acordo com: ASSOCIAÇÃO BRASILEIRA DE NORMAS TÉCNICAS. NBR 6023: Informação e documentação: referências: elaboração. Rio de Janeiro, 2002. 
CZARINA ACELAJADO, M.; CALHOUN, D. A. Treatment of resistant hypertension. Minerva Cardioangiol., v. 57, n. 6, p. 787-812, 2009.

DECARIE, A.; RAYMOND, P.; GERVAIS, N.; COUTURE, R.; ADAM, A.; Serum interspecies differences in metabolic pathways of bradykinin and [des-Arg ${ }^{9}$ ]BK: influence of enalaprilat. Am. J. Physiol., v. 270, p. H1340-1347, 1996.

DENDORFER, A.; WOLFRUM, S.; DOMINIAK, P. Pharmacology and cardiovascular implications in kinin-kallikrein system. JPN J. Pharmacol., v. 79 p. 403-426, 1999.

DRUMMOND, G. R.; COCKS, T. M. Endothelium-dependent relaxation mediated by inducible $\mathrm{B} 1$ and $\mathrm{B} 2$ constitutive kinin receptors in the bovine isolated coronary artery. Br. J. Pharmacol., v. 116, n. 5, p. 2473-2481, 1995a.

DUKA, I.; KINTSURASHVILI, E.; GAVRAS, I.; JOHNS, C.; BRESNAHAN, M.; GAVRAS, $\mathrm{H}$. Vasoactive potential of the $\mathrm{B} 1$ bradykinin receptor in normotension and hypertension. Circ. Res., v. 88, n. 3, p. 275-281, 2001.

DUKA, A.; KINTSURASHVILI, E.; DUKA, I.; ONA, D.; HOPKINS, T. A.; BADER, M.; GAVRAS, I.; GAVRAS, $H$. Angiotensin-converting enzyme inhibition after experimental myocardial infarct: role of the kinin B1 and B2 receptors. Hypertension, v. 51, n. 5 , p. $1352-1357,2008$.

EMANUELI, C.; CHAO, J.; REGOLI, D.; CHAO, L.; NI, A.; MADEDDU, P. The bradykinin B1 receptor and the central regulation of blood pressure in spontaneously hypertensive rats. Br. J. Pharmacol., v. 126, n. 8, p. 1769-1776, 1999.

EMANUELI, C.; SALIS, M. B.; STACCA, T.; PINTUS, G.; KIRCHMAIR, R.; ISNER, J. M.; PINNA, A.; GASPA, L.; REGOLI, D.; CAYLA, C.; PESQUERO, J. B.; BADER M.; MADEDDU, P. Targeting Kinin B1 receptor for therapeutic neovascularization. Circulation, v. 105, n. 3, p. 360-366, 2002.

ERDÖS, E. G. Angiotensin I converting enzyme. Circulation Research, v. 36, n. 2, p. 247-255, 1975.

FERNANDES, L.; CERAVOLO, G.S.; MORI, M. A. S.; PESQUERO, J. B.; CARVALHO, M. H. C. Modulation of Kinin B1 receptor expression by endogenous angiotensin II in hypertensive rats. Peptides, v. 136, n. 1-3, p. 92-97, 2006. 
FERRARIO, C. M. Role of angiotensin II in cardiovascular disease therapeutic implications of more than a century of research. J. Renin Angiotensin Aldosterone Syst., v. 7, n. 1, p. 3-14, 2006.

FOUCART, S.; GRODIN, L.; COUTURE, R.; NADEU, R. Modulation of noradrenaline release by $\mathrm{B} 1$ and $\mathrm{B} 2$ kinin receptor during metabolic anoxia in the rat isolated atria. Can. J. Physiol. Pharmacol., v. 75, n. 6 , p. 639-645, 1997.

GOHLKE, P.; LINZ, W.; SCHÖLKENS, B. A.; KUWER, I.; BARTENBACH, S.; SCHNELL, A.; UNGER, T. Angiotensin-converting enzyme inhibition improves cardiac function - role of bradykinin. Hypertension, v. 23, p. 411-418, 1994.

GOLDBLATT, H.; LYNCH, J.; HANZAL, RF.; SUMMERVILLE, WW.:.Studies on experimental hypertension : i. The production of persistent elevation of systolic blood pressure by means of renal ischemia J. Exp. Med., v. 28, n. 3, p. 347-379, feb 1934.

HAGIWARA, M.; MURAKAMI, H.; URA, N.; AGATA, J.; YOSHIDA, H.; HIGASHIURA, K.; SHIMAMOTO, K. Renal protective role of bradykinin B1 receptor in stroke-prone spontaneously hypertensive rats. Hypertens. Res., v. 27, n. 6, p. 399-408, 2004.

HESS, J. F.; BORKOWSKY, J. A.; YOUNG, G. S.; STRADER, C. D., RANSOM, R. W. Cloning and pharmacological characterization of a human bradykinin (BK-2) receptor. Biochem. Biophys. Res. Commun., v. 184, n. 1, p. 260-268, 1992.

IGNJATOVIC, T.; TAN, F.; BROVKOVYCH, V.; SKIDGEL, R. A.; ERDÖS, E. G. Novel mode of action of angiotensin I converting enzyme inhibitors: direct action of bradykinin B1 receptor. J. Biol. Chem., v. 277, n. 19, p. 16847-16852, 2002.

ITO, K.; ZHU, Y.Z.; ZHU, Y.C.; GOHLKE, P.; UNGER, T.; Contribution of bradykinin to the cardioprotective action of angiotensin converting enzyme inhibition in hypertension and after myocardial infarction. Jpn. J. Pharmacol., v. 5, p. 311-318, 1997.

KINTSURASHIVILI, E.; DUKA, I.; GAVRAS, I.; JOHNS, C.; GAVRAS, H. Effects of ANG II on bradykinin receptor gene expression in cardiomyocytes and vascular smooth muscle cells. Am. J. Physiol. Heart Circ. Physiol., v. 281, n. 4, p.H17781783, 2001.

LARRIVÉ, J. F.; BACHVAROV, D. R.; HOULE, F.; LANDRY, J.; HUOT, J.; MARCEAU, F. Role of the mitogen-activated protein kinases in the expression of the 
kinin B1 receptors induced by tissue injury. J. Immunol., v. 160, n. 3, p. 1419-1426, 1998.

LINZ, W.; WIEMER, G.; GOHLKE, P.; UNGER T.; SCHÖLKENS, B. A. Contribution of kinins to the cardiovascular actions of angiotensin-converting enzyme inhibitors. Pharmacol. Rev., n. 47, v. 1, p. 25-49, 1995.

LIPP, M. N.; ROCHA, C. J. Stress, Hipertensão Arterial e qualidade de Vida: um guia de tratamento. 2. ed. Campinas, SP: Papirus, 1996.

LI, J. M.; SHAH, A. M. Endothelial cell superoxide generation: regulation and relevance for cardiovascular pathophysiology. Am. J. Physiol. Regul. Integr. Comp. Physiol., v. 287, n. 5, p. R1014-R1030, 2004.

LOPES HF, SILVA HB, CONSOLIM-COLOMBO FM, BARRETO FILHO JA, RICCIO GMG, GIORGI DMA, KRIEGER EM. Autonomic abnormalities demonstrable in young normotensive subjects who are children of hypertensive parents. Brazilian Jornal of Medical and Biological Research 33:1-4, 200

MANO, R. Manuais de Cardiologia. Disponível em: http.www.manuaisdecardiologia.méd.br. Acesso em: 26 mar. 2010.

MADEDDU, P.; VARONI, M. V.; PALOMBA, D.; EMANUELI, C.; DEMONTIS, M. P.; GLORIOSO, N.; DESSÌ-FULGHERI, P.; SARZANI, R.; ANANIA, V. Cardiovascular phenotype of a mouse strain with disruption of bradykinin B2-receptor gene. Circulation, v. 96, n. 10, p. 3570-3578, 1997.

MARCEAU, F. Kinin B1 receptors: a review. Immunopharmacology, v. 30, n. 1, p. 1-26, 1995.

MARCEAU, F.; HESS, J. F.; BACHVAROV, D. R. The B1 receptors for kinins. Pharmacol. Rev., v. 50, n. 3, p. 357-386, 1998.

MARIN-CASTANHO, M. E.; SCHANSTRA, J. P.; NEAU, E.; PRADDAUDE, F.; PECHR, C.; ADER, J. L.; GIROLAMI, J. P.; BASCANDS, J. L. Induction of functional bradykinin B1-receptors in normotensive rats and mice under chronic angiotensin converting-enzyme inhibitor treatment. Circulation, v. 105, p. 627-663, 2002. 
MC LEAN, P. G.; PERRETTI, M.; AHLUWALIA, A. Inducible expression of kinin B1 receptor in the endotoxemic heart: mechanisms of des-Arg ${ }^{9}$ bradykinin-induced coronary vasodilatation. Br. J. Pharmacol.; v. 128, n. 2, p. 275-282, 1999.

NAKHOSTINE, N.; RIBUOT, C.; LAMONTAGNE, D.; NADEAU, R.; COUTURE R. Mediation by $\mathrm{B} 1$ and $\mathrm{B} 2$ receptors of vasodepressor responses to intravenously administred kinin in anaesthetized dogs. Br. J. Pharmacol., v. 110, n. 1, p. 71-76, 1993.

$\mathrm{NI}$, A.; CHAO, L.; CHAO, J. Transcription factor nuclear factor $\kappa \mathrm{B}$ regulates the inducible expression of the human B1 receptor gene in inflammation. J. Biol. Chem., v. 273, n. 5, p. 2784-2791, 1998.

KEARNEY, P. M.; WHELTON, M.; REYNOLDS, K.; MUNTNER, P.; WHELTON, P. K.; HE, J. Global burden of hypertension: analysis of worldwide data. Lancet, v. 365, n. 9455, p. 217-223, 2005.

KINTSURASHIVILI, E.; DUKA, I.; GAVRAS, I.; JOHNS, C.; FARMAKIOTIS, D.; GAVRAS, $H$. Effects of ANG $\|$ on bradykinin receptor gene expression in cardiomyocytes and vascular smooth muscle cells. Am. J. Physiol. Heart Circ. Physiol., n. 281, n. 4, p. H1778-H1783, 2001.

PESQUERO, J. B.; ARAUJO, R. C.; HEPPENSTALL, P. A.; STUCKY, C. L.; SILVA, J. A. JR.; WALTHER, T.; OLIVEIRA, S. M.; PESQUERO, J. L.; PAIVA, A. C.; CALIXTO, J. B.; LEWIN, G. R.; BADER, M. Hypoalgesia and altered inflammatory responses in mice lacking kinin B1 receptors. PNAS, v. 97, n. 14, p. 8140-8145, 2000.

PRUNEAU, D.; BELICHARD, P. Induction of bradykinin $\mathrm{B}_{1}$ receptor-mediated relaxation in the isolated rabbit carotid artery. Eur. J. Pharmacol., v. 239, n. 1-3, p. 63-67, 1993.

PRUNEAU, D.; LUCCARINI, J. M.; DEFRENE, E.; PAQUET, J.L.; BELICHARD, P. Characterisation of bradykinin receptors from juvenile pig coronary artery. Eur. J. Pharmacol., v. 297, n. 1-2, p. 53-60, 1996.

QUADRI, F.; HÄUSER, W.; JÖUREN, O.; DOMINIAK, P. Kinin B1 and B2 receptor mRNA expression in the hypothalamus of spontaneously hypertensive rats. Can. J. Physio. Pharmacol., v. 80, n. 4, p. 258-263, 2002. 
REGOLI, D.; BARABÉ, J. Pharmacology of bradykinin and related kinins. Pharmacol. Rev., v. 32, n. 1, p. 1-46, 1980.

REGOLI, D. C.; NSA, A. S.; RIZZI, A.; GOBEIL, F. J. Bradykinin receptors and their antagonists. Eur. J. Pharmacol., n. 348, p.1-10, 1981.

SANTOS, R. A. S.; CAMPAGNOLE-SANTOS, M. J.; BARACHO, N. C. V.; FONTES, M. A.; SILVA, L. C.; NEVES, L. A.; OLIVEIRA, D. R.; CALIGIORNE, S. M.; RODRIGUES, A. R.; GROPEN JÚNIOR, C.; et al. Characterization of a new angiotensin antagonist selective for angiotensin-(1-7): evidence that the actions of angiotensin-(-1-7) are mediated by specific angiotensin receptors. Brain Res. Bull., v. 35, n. 4, p. 293-298, 1994.

SANTOS, C. F.; CAPRIO, M. A.; OLIVEIRA, E. B.; SALGADO, M. C.; SCHIPPERS, D. N.; MUNZENMAIER, D. H.; GREENE, A. S. Functional role, cellular source, and tissue distribution of rat elastase-2, an angiotensin II-forming enzyme. Am. J. Physiol. Heart Circ. Physiol., v. 285, n. 2, p. H775-H783, 2003.

SCHANSTRA, J. P.; BATAILLÉ, E.; MARIN CASTAÑO, M. E.; BARASCUD, Y.; HIRTZ, C.; PESQUERO, J. B.; PECHER, C.; GAUTHIER, F.; GIROLAMI, J. P. ; BASCANDS, J. L. The B1-agonist [des-Arg ${ }^{10}$ ]-kallidin activates transcription factor $\mathrm{NF}-\kappa \mathrm{B}$ and induces homologous upregulation of the bradykinin B1-receptor in cultured human lung fibroblasts. J. Clin. Invest., v. 101, n. 10, p. 2080-2091, 1998.

SCHIFFRIN, E. L. Reactivity of small blood vessels in hypertension:relation with structural changes. State of the art lecture. Hypertension, v. 19, p. II-1-II-9, 1992. Supplement II.

SCHIFFRIN, E. L. Vascular and cardiac benefits of angiotensin receptor blockers. Am. J. Med., v. 113, n. 5, p. 409-418, 2002.

SCHNECK, K. A.; HESS, J. F.; STONESIFER, G. Y.; RANSOM, R. W. Bradykinin B1 receptors in rabbit aorta smooth muscle cells in culture. Eur. J. Pharmacol., v. 266, n. 3, p. 277-282, 1994.

SCHÖLKENS, B. A. Kinins in the cardiovascular system. Immunopharmacology, v. 33, p. 209-216, 1996

SHARMA, J. N. Hypertension and the Bradykinin System. Current Hypertension Reports, v. 11, n. 3, p. 178-181, 2009. 
SIEBECK, M.; WHALLEY, E.T.; HOFFMANN, H.; WEIPERT, J.; FRITZ, H. The hypotensive response to des-Arg9-bradykinin increases during $E$. coli septicemia in the pig. Adv. Exp. Med. Biol., v. 247B, p. 389-393, 1989.

SILVERSTEIN, R. L.; FENVES, A. Z.; RAM, C. V. ARBs and target organ protection. Exploring benefits beyond their antihypertensive effects. Postgrad. Med., v. 116, n. 2, p. 31-38, 2004.

SU, J. B.; HOÜEL, R.; HÉLOIRE, F.; BARBE, F.; BEVERELLI F.; SAMBIN, L.; CASTAIGNE, A.; BERDEAUX, A.; CROZATIER, B.; HITTINGER, L. Stimulation of bradykinin $B 1$ receptors induces vasodilation in conductance and resistance coronary vessels in conscious dogs. Comparison with B2 receptor stimulation. Circulation, v. 101, n. 15, p. 1848-1853, 2000.

TSCHÖPE, C.; GOHLKE P.; ZHU T. Antihypertensive and cardioprotective effects after angiotensin-converting enzyme inhibition: role of kinins. J. Card. Fail, v. 3, p. 133-148, 1997

TOUYZ, R. M.; SCHIFFRIN, E. L Signal transduction mechanisms mediating the physiological and pathophysiological actions of angiotensin II in vascular smooth muscle cells. Pharmacol. Rev., v. 52, n. 4, p. 639-672, 2000.

WAGENAAR, L. J.; VOORS, A. A.; BUIKEMA, H.; VAN GILST, W. H. Angiotensin receptors in the cardiovascular system. Can. J. Cardiol., v. 18, n. 12, p. 1331-1339, 2002.

WEIR, M. R.; DZAU, V. J. The renin-angiotensin-aldosterone system: a specific target for hypertension management. Am. J. Hypertens., v. 12, n. S9, p. 205S-213S, 1999.

WOHLFART, P.; DEDIO, J.; WIRTH K.; SCHÖLKENS B. A.; WIEMER, G. Different B1 kinin receptor expression and pharmacology in endothelial cells of different origins and species. J. Pharmacol. Exp. Ther., v. 280, n. 2, p. 1109-1116, 1997.

ZWEIFACH, B. W. Indirect methods for regional blood flow. I. Microscopic observation of circulation in rat mesoappendix and dog omentum. Use in study of vasotropic substances. Methods Med. Res., v. 1, p. 131-138, 1948. 